\title{
The Language of Feeling in Njáls saga and Egils saga: Construction of an Emotional Lexis
}

\author{
BRYNJA PORGEIRSDÓTTIR
}

\section{Introduction}

Íslendingasögur (Sagas of Icelanders) are notorious for the apparent emotional reticence of their narrative style. As a rule, the narrative voice is externally focalised and emotional expression in the prose is mainly implicit; feelings are communicated through behaviour, physical reactions, and indirect allusions, and most often need to be inferred (Sävborg 2007: 246; Sif Rikhardsdottir 2017: 71-78; Miller 1992: 94-97). ${ }^{1}$

For example, the feelings of the Norwegian king's mother, Gunnhildr, and the erotic love she holds for the Icelandic chieftain Hrútr at the beginning of Brennu-Njáls saga, are never explicitly stated with emotion words. Instead, her passionate emotions are conveyed by her action and gestures, by the many gifts she gives Hrútr, and her locking herself in her chambers with him for two weeks after announcing to him: "Pú skalt liggja í lopti hjá mér í nótt, ok vit tvau saman" (Brennu-Njáls saga 1954: 15), 'You shall lie in my chambers tonight, and us two together'. Furthermore, her

\footnotetext{
${ }^{1}$ Concerning the laconic saga-style in general, the chapter on Íslendingasögur in Íslensk stílfraðði (Porleifur Hauksson and Pórir Óskarsson 1994) remains one of the most comprehensive analysis. Sävborg (2017) furthermore provides a thorough discussion on external focalization in this context.

${ }^{2}$ Page numbers in brackets refer to the Íslenzk fornrit editions. All translations in this essay are my own.
}

Porgeirsdóttir, Brynja. 2020. The Language of Feeling in Njáls saga and Egils saga:

Construction of an Emotional Lexis. Scripta Islandica 71: 9-50.

(C) Brynja Porgeirsdóttir (CC BY)

DOI: $10.33063 /$ diva-429319 
feelings are indicated by her gestures as she kisses Hrútr while casting a spell on him when he leaves her: that he will not be able to have any physical pleasure with the woman he plans to marry (21). Similar style is applied in the description of teenage Egill's wrath in Egils saga, when his brother announces to Egill's disappointment that there is no chance that he will take him abroad with him (Egils saga 1933: 102). Egill's rage at this is not communicated with emotion words, but it is tangible and vividly expressed with his subsequent sabotage of his brother's ship, and his threats of doing more harm towards Pórólfr if he didn't take him away with him (102-3). In the background, a storm rages in the black night, functioning as a reflection of Egill's turbulent emotional state (102-3).

Nevertheless, emotion words are indeed found in Íslendingasögur. However, the extent of the part they play in the sagas' depiction of feelings what explicit emotion words are used, how, by whom, and in what context - has not been the focus of studies on emotions in saga literature. While a variety of studies on emotion terms have been conducted within classical studies (Kaster 2005) and surveys of texts of the medieval West (Rosenwein 2008, 2010), a comprehensive study of Old Norse emotion vocabulary, and how it is used, has yet to be made. In the absence of such a lexical investigation, the question arises as to what extent assertions such as that of Kirsten Wolf, that Íslendingasögur are "poor in emotional vocabulary" (Wolf 2014: 143), can be taken as truisms - or William Ian Miller's claim that readers of the sagas are "seldom assisted by native emotions words" (Miller 1992: 107). Without a point of comparison, it cannot be ascertained with clarity what "poor" or "seldom" signify in this context. This drives a closer inquiry regarding the extent feelings are expressed with emotion words in the sagas and what function these words have within them.

This subject has been approached to some extent. In his 1994 essay, "Emosjon og aksjon i Njáls saga", Vésteinn Ólason explores the theme of honour in Njáls saga through nouns that refer to emotions. Vésteinn finds only fourteen nouns in the saga that describe emotions. These nouns, he finds, are used 117 times in the saga, and the majority are words for friendship: vinr 'friend', vinátta 'friendship', and vinfengi 'friendship'. Vésteinn concludes that "[f]ølelser sjelden blir nevnt med ord, og at ordforrådet ikke er særlig nyansert [...] Njáls saga bruker et enkelt ordforråd for a beskrive emosjoner" (1994: 164) ('Emotions are rarely mentioned with words and the vocabulary is not very nuanced [...] Njáls saga uses a simple vocabulary to describe emotions'). Vésteinn does not say why he limits his investigation to nouns, nor explain the criteria behind the selection of words. For example, 
his study does not include the nouns hraesla 'fear', hugleysi 'cowardice', áhyggja 'anxiety' or 'worry', œði 'rage', ópokki 'hostility', blíða 'affection', and many others found in the saga, as seen in Table 2 below.

In her essay, "Learning to Feel in the Old Norse Camelot?", Carolyne Larrington explores whether translated romances influenced the emotional style of native Old Norse sagas and includes a "preliminary analysis of emotion lexis" in different genres of Old Norse literature with examples from poetry and prose (Larrington 2015: 86). As Larrington notes, "it is evident that Old Norse already possessed a full lexis of emotion [...] in the early thirteenth century", which was capable of expressing both basic and complex feelings (86). Her preliminary analysis "indicates that a more intensive lexical investigation would be fruitful" (86). ${ }^{3}$

Larrington's conclusion here serves as a premise for the following analysis. In what follows, the emotional vocabulary of Egils saga and Njáls saga is listed and analysed to assess the significance and function of emotion words in the two sagas. In the absence of comprehensive studies on the topic, the prerequisite for reaching this goal is to define the design and methods for the construction of such a lexicon. In this essay, a method of building lexicons of emotion words extracted from these two sagas is laid out. The lexicons are presented, followed by an analysis and conclusions. The aim is to probe what themes emerge from the lexicons and what they reveal about the use of emotion words within the texts.

\section{Method}

To understand how much emotion words weigh in the depiction of feelings in Njáls saga and Egils saga, the sagas were scrutinized for words expressing an emotional state. ${ }^{4}$ This entailed a close reading of the

\footnotetext{
${ }^{3}$ See also Daniel Sävborg's monumental study of love in Old Norse literature, which includes an investigation of the words used for love in Íslendingasögur (Sävborg 2007: 36-43). Furthermore, Sif Rikhardsdottir (2017: 64-71) discusses the function of a handful of emotion words in Egils saga. Edel Porter and Teodoro Manrique Antón (2015) investigate the occurrences of words that include somatic markers of emotion in a variety of Old Norse texts.

${ }^{4}$ The editions used to build the lexicon were edited by Jón Torfason and others, published by Svart á hvítu in 1985. This is because the texts of the Svart á hvítu editions form the searchable database Mörkuð islensk málheild: Fornrit and are available in digital form. In the case of Njáls saga, this edition is based on the 1875-1889 edition of Konrád Gíslason
} 
standard editions of the sagas, word for word, line by line. Emotion words (defined below) were extracted from the text and entered onto digital datasheets. In each case, the names of the involved characters, their gender and societal rank, the speaker, and any consequences were noted. This was done to enable the plotting of each of these variables against any of the others to uncover possible correlations and narrative and linguistic patterns to extract statistical information. Each entry was verified, and the list was refined using electronic versions and the database Mörkuð islensk málheild. The words in the lexicon were then categorized into prominent categories, significant themes, and narrative formulas for further analysis. The process involved disparate obstacles and considerations, which are described in the following sections.

\subsection{Selection of words}

The selection of the words posed several challenges. First, there is the question of what qualifies as a word that refers to an emotion. The chosen method is based on a simple linguistic test developed by Clore, Ortony, and Foss (1987), which has been used in the semantic analysis of emotion words in psychological research (Johnson-Laird and Oatley 1989). To differentiate between emotional and non-emotional terms, the test distinguishes between two different contexts. One is the context of feeling something, and the other is being something. Thus, "angry" is categorized as a genuine emotion term because the subjects of the above study rated both "feeling angry" and "being angry" as emotions. However, "abandoned" is not an emotion term because "feeling abandoned" is rated as an emotion, whereas "being abandoned" is not. This test was used as a basic reference point when collecting words from the text. Compound

and Eiríkur Jónsson, where Reykjabók (AM 468 4to), dated to 1300-1325, is the base manuscript, with minor emendations from the Íslenzk fornrit edition, which is based on mid-fourteenth century Möðruvallabók (AM 132 fol.). In the case of Egils saga, this edition is based on Finnur Jónsson's 1886-88 edition of the saga, with minor emendations and supplements from Bjarni Einarsson. These, and the Íslenzk fornrit edition of Egils saga, all have Möðruvallabók as the base manuscript. Each entry in the lexicon was subsequently verified in the Íslenzk fornrit editions of the sagas, and the few deviations that occur are noted in footnotes. However, the poetry of Njáls saga in the Íslenzk fornrit edition that is not included in the Svart á hvítu edition is included in this study. Other editions and manuscripts were not systematically searched but were consulted for comparison in individual cases, and these instances are noted in the footnotes. 
words were added to this that include an emotion word as well as short phrases and idioms that refer to an emotional state.

However, the general concept of "emotion words" admittedly has a fuzzy boundary, and the process is far from absolute. There are words that hover on the border of any definition of emotions, such as the more than two hundred instances of góðr 'good' that appear in the sagas. Góðr can semantically refer to "being kind" in addition to "the good quality" of something. On further analysis, in most cases in the two sagas, gódr proved to refer to an act or a quality but not to a feeling of kindness. However, this is unclear in some cases or even unintelligible from the text. Given the circumstances, góðr is not included in the lexicon.

More, but less frequent, words have an ambivalent meaning, where the context and placement of the word in the text in each case had to be considered to determine whether it denotes an expression of emotion. For example, angr is an emotion word denoting sadness in the translated romance Parcevals saga, as Larrington (2015: 85) has discussed. She transfers this meaning to the same word in Njáls saga (87). However, in the context in which it appears in Njáls saga (1954: 457), angr denotes "material damage", "trouble", or "harm" done to someone, rather than sad feelings. ${ }^{5}$ Thus, it is not included in this lexicon. Another example is the verb hressa and its reflexive form hressask, which can mean both "to cheer up" and "to recover one's strength". For this word, the lexicons only count the occurrences that clearly and evidently refer to the former meaning because that sense refers to emotions, but the other does not.

Second, the fact that the textual material is from a distant culture and written in a foreign language must be considered. As has been demonstrated in numerous ethnographic and linguistic studies, emotion concepts and emotion categories vary across time periods, languages, and cultures. A semantic comparison across languages and cultures can prove highly precarious (Wierzbicka 1999: 24-31; Goddard and Wierzbicka 2014: 8-10; Russell 1991: 429-33) and invites the risk of an anachronistic bias, resulting in words and terms being overlooked or that meaning is transferred onto them that they do not impart. An emotion word in one language sometimes does not even exist in others. For example, the German word Schadenfreude, 'delight in another person's misfortune', has no equivalent in English. This same view applies when studying past

\footnotetext{
${ }^{5}$ See Einar Ól. Sveinsson's commentary in Brennu-Njáls saga (1954: 457) and "angur" in Íslensk orðabók (Mörður Árnason 2007).
} 
cultures and languages. As Shweder and others emphasize, the goal is to "render the meaning of other people's mental states without assimilating them in misleading ways to an a priori set of lexical items available in the language of the researcher." (Shweder et al. 2008: 424).

A case in point is vinátta "friendship'. In the modern sense, "friendship" and the Modern Icelandic corresponding term vinátta would be viewed as a word expressing feelings of affection. In Njáls saga and Egils saga, however, vinátta and vinr 'friend' most often refer to political alliances and practical social bonds - not to an internal state of feelings of affection. ${ }^{6}$ Thus, it is often discussed in relation to forming an alliance, such as with a king in Egils saga: "Segðu svá konungi, at ek mun vera vinr hans" (Egils saga 1933: 13), 'Tell the King that I will be his friend', and in Njáls saga, when Gizurr pleads to Gunnarr to form an alliance with Otkell by requesting: "pess beiðu vér, at pú sér vinr Otkels" (ВrennuNjáls saga 1954: 132), 'We ask that you become a friend to Otkell'. Here, Gizurr is far from suggesting that Otkell and Gunnarr become affectionate confidants but is suggesting that they form a practical alliance where Otkell could count on Gunnarr's political support. As Jón Viðar Sigurðsson demonstrates in his analysis of friendship in Iceland c. 900-1300: "friendship ties might best be compared to a contract between two parties with clear reciprocal obligations. Feelings often had little to do with it." (Jón Viðar Sigurðsson 2017: 3). The vast majority of the occurrences of the words vinr, vinátta, and vinfengi in the two sagas clearly refer to such a "contract", although it admittedly remains ambiguous in odd cases if affection is perhaps additionally being alluded to. These words are thus not included in the lexicon. However, the word ástvinátta 'affectionate friendship' is included owing to the prefix ást- (Egils saga 1933: 284), which clearly denotes affectionate feelings. Furthermore, it is sometimes noted that vinátta 'friendship' is karr 'dear' (Egils saga 1933: 3; BrennuNjáls saga 1954: 168); and the word karr is included in the lexicon.

"Shame", in particular, is discussed here because honour is a prominent theme in the genre of Íslendingasögur. However, the Modern English word "shame" emerges as a very problematic term to assimilate directly to other cultures (Shweder et al. 2008: 418-20; Russell 1991: 430-31). Skoqmm is one of the words Larrington classifies as an emotion word and translates it

\footnotetext{
${ }^{6}$ See examples of vinátta 'friendship' in Egils saga $(1933: 13,88,214)$ and in Brennu-Njáls saga (1954: 122, 168, 200), and of vinr 'friend' in Egils saga $(1933: 15,20)$ and in BrennuNjáls saga (1954: 12, 132, 286).
} 
to English as "shame" (Larrington 2015: 87-88). This particular English word is defined in the Oxford English Dictionary $(O E D)$ as a "painful emotion arising from the consciousness of something dishonouring, ridiculous, or indecorous in one's own conduct or circumstances". A different, non-emotional definition of "shame" is also offered: a "loss of esteem or reputation". Skomm has both these meanings in Old Norse and Modern Icelandic, although the latter meaning is more common. ${ }^{7}$ Skomm and related words, as well as the antonym sæm 'honour', are certainly frequent in Njáls saga, where honour and humiliation are prominent themes. ${ }^{8}$

However, it can be argued that skomm, as it appears in Njáls saga, does not refer to an inner state of feeling shame or being ashamed. Rather, it refers to a social context: by behaving in a certain way, the characters can suffer a loss of status and reputation or are at the risk of suffering dishonour in the eyes of others. The meaning in this context does not include the person feeling shame. This is the case in all instances of the word in Njáls saga.

Two examples will be taken here to illustrate this point. First, Rannveig's famous words to her daughter-in-law, Hallgerðr: "Illa ferr pér, ok mun pín skọmm lengi uppi.” (Brennu-Njáls saga 1954: 189), 'Your actions are wicked, and your dishonour will be long-lasting'. This does not mean that Hallgerðr will feel shameful for a long time. "Lengi uppi" refers to something being remembered by the public for a long time. Therefore, the sense is that Hallgerðr will be regarded as dishonourable in the eyes of others for a long time, but the saga is silent about Hallgerðr's emotions in this scene. Another representative example is from Gunnarr's final battle, when he picks up his enemies' arrow and shoots it back at them and says: "er peim pat skǫmm, ef peir fá geig af vápnum sínum" (187), 'it is a disgrace for them, if they are harmed by their own weapons'. Gunnarr is commenting here on how ignominious it would appear for his opponents to be hurt by their own weapons. Whether his enemies will feel any shame or self-loathing is not indicated, only that this would result in other members of society thinking less of them. Furthermore,

\footnotetext{
${ }^{7}$ See the 180 examples in the database Ordbog over det norrøne prosasprog. For different meanings in Modern Icelandic, see "skömm" in Íslensk orðabók (Mörður Árnason 2007). ${ }^{8}$ The word appears thirteen times in Brennu-Njáls saga (1954) in the genitive (skammar) on 114, 345, and on 417 in the combination skammarvíg. Nominative and accusative forms (skomm) appear on 137, 149, 187, 189, 315, 330, 372 (twice) and 402. This corresponds to the Svart á hvítu edition, which adds one more case of skomm on 269, included here because that edition is the basis of this lexicon.
} 
this sense of the word skomm seems to apply to all ten cases of skomm's synonyms in Njáls saga. ${ }^{9}$ The same applies to Egils saga. Skoqmm is thus not included in this lexicon, nor are words from the same category, such as svivirðing, sneypa, and óvirðing. However, this does not mean that the feeling of skomm is not expressed in the sagas through other modes, such as action and various verbal means that denote the feeling of shame and humiliation (see Miller 1993: 116-130).

\subsection{Problems of categorization and the prototype approach}

To analyse and compare the size of the vocabulary for different emotions, the words need to be categorized. The question arises what emotion categories apply to Old Norse sagas? Modern psychologists, on the basis of recognition of emotions from facial expressions across cultures, have claimed that there is a set of universal basic emotions. Paul Ekman has argued that there are seven: ANGER, FEAR, SURPRISE, SADNESS, DISGUST, CONTEMPT, and HAPPINESS (Ekman 1994; Ekman and Cordaro 2011: 365-66). The basic emotional modes are only five according to Johnson-Laird and Oatley (1989: 90), who leave out Ekman's SURPRISE and CONTEMPT. Carrol Izard's fundamental emotions number ten, among them are INTEREST and GUILT, which are not on the other lists (1977: 85-92).

However, the concept of basic emotion is not useful as means of determining lexicographical categories when it comes to literary works from a distant culture. Irrespective of how universal or basic some emotions might be, an abundance of ethnographic and linguistic evidence demonstrates that emotions are defined and categorized in different ways across languages and cultures (Wierzbicka 1986: 585-87; Russell and Lemay 2000: 496; Shweder et al. 2008: 424). How (basic or not) emotions are described, expressed, termed, and categorized in different communities is culturally relative. Lists of emotions and categories of emotion have been made from ancient times by Aristotle, Plato, Cicero, Aquinas, and others, which Barbara Rosenwein (2008) and Simo Knuuttila (2004) provide a good summary of, and they are all different. This illustrates that, for the present purpose, it is misleading at best to apply previously set categories from a different culture using a different language to the lexis here.

\footnotetext{
${ }^{9}$ Synonyms appear ten times, svívirðing on 28 and twice on 226; svívirða 341; svívirðiligr (adj.) 372, 432 and additionally on 139 in the Svart á hvítu edition, but the same place in the Îslenzk fornrit edition reads skǫmm (36). Sneypa appears on 130, 306; óvirðing 371.
} 
Considering the above, it would be most useful to assess the emotion words in the sagas in relation to the prototype approach, which is a framework used to conceptualize people's knowledge on emotions in psychological research. ${ }^{10}$ The approach entails the conceptualization of people's knowledge of emotions as organized around prototypes in a graded structure, similar to a colour spectrum. Emotion words form clusters or groups around the prototypes, and further, the words and groups are organized within a hierarchy from abstract to concrete, such as POSITIVE EMOTIONS $>$ LOVE $>$ AFFECTION $>$ ENDEARMENT. This framework assumes a necessary fluidity and some degree of overlap between categories with a flexibility that makes it particularly useful in its application for the present purpose. Based on this, presupposed categories were not used to categorize the words in the two lexicons in this study. Instead, clusters were formed by gradually grouping words together and considering them one by one based on the similarity of their meaning. The categories do not refer to the idea of basic emotions but to the broad themes emerging from the grouping of the words according to their meaning. When the emotion categories had been identified (ten for Njáls saga and nine for Egils saga), the words were organized in a hierarchy with overarching categories and subordinate categories.

The method forms a layered structure where the emotion words within each domain group reflect finer gradations of their head category, and their similarity can be a matter of degree. For example, the words allreiðr 'very angry' and styggr 'morose, irritated' both belong to the ANGER category of Egils saga, but the former denotes a much more intense form of the feeling of anger than the latter. Two categories of POSITIVE and NEGATIVE emotions are at the superordinate level of each lexicon. The middle level forms the positive categories of JOY, LOVE, COURAGE, and TRANQUILLITY, and the negative categories of ANGER, FEAR, SADNESS, and CONTEMPT and the category SURPRISE, which includes (in Njáls saga) both negative and neutral words. Where applicable, opposing categories of feelings are paired in Tables 1 and 2 below. The negative category of ENVY additionally emerged from Njáls saga. Some of the mid-level categories (FEAR, COURAGE, and LOVE) are divided into subcategories, but not completely identically for both sagas, as the lexicon for Njáls saga includes two subcategories

\footnotetext{
${ }^{10}$ Pioneering work on the prototype approach is by Eleanor Rosch (1978). On the application of the probabilistic/prototype approach, see Niedenthal (2008: 592-93); Russell and Lemay (2000: 494-95).
} 
Tab. 1. Words referring to an emotional state in Egils saga. Numbers following each heading refer to how many words are in the category. Numbers in parenthesis refer to the frequency. The absence of a number indicates the word occurs only once.

\begin{tabular}{|c|c|c|c|}
\hline Egils saga, negative & & Egils saga, positive & \\
\hline SADNESS 8 (22) & & JOY $18(41)$ & \\
\hline allókátr, adj. & 'very unhappy, sad' & allfeginn, adj. & 'very glad, joyful' \\
\hline harma, v. & 'mourn' & allfeginsamliga, adv. & ‘very joyfully’ \\
\hline harmdauði, adj. & 'mourned' & allglaðr, adj. & 'very glad' \\
\hline harmr, n. (8) & 'grief' & allkátr, adj. (8) & 'very cheerful, happy' \\
\hline hryggr, adj. & 'sad, grieved' & einteiti, adj. & 'in very good spirits' \\
\hline ógleði, n. (5) & 'unhappiness, sadness' & feginn, adj. (5) & 'glad, joyful' \\
\hline ókátr, adj. (4) & 'unhappy, sad' & feginsamliga, adv. (5) & ‘joyfully’ \\
\hline \multirow[t]{11}{*}{ sorg, n. } & 'grief, sorrow' & glaða, v. & 'gladden' \\
\hline & & glaðr, adj. & 'glad' \\
\hline & & gleði, n. (3) & 'gladness, merriment' \\
\hline & & gleðimaðr, n. (2) & 'a cheery man' \\
\hline & & gleðja, v. (3) & 'gladden, enliven' \\
\hline & & glýjaðr, adj. & 'gleeful, cheerful' \\
\hline & & hressa, v. (3) & 'cheer up' \\
\hline & & í góðu (adj.) skapi & 'in good spirits’ \\
\hline & & kátr, adj. (2) & 'cheerful, happy’ \\
\hline & & léttr, adj. & 'cheerful' \\
\hline & & óhryggr, adj. & lit.: 'un-grieved' \\
\hline FEAR 9 (14) & & COURAGE 10 (21) & \\
\hline - Fear & & - Bravery & \\
\hline hræðask, v. (3) & 'be afraid of, fear' & fullhugi, n. & 'man without fear' \\
\hline hræðslugœði, n. & 'fear, actions from fear' & hafa (v.) hug & 'have courage' \\
\hline óask, v. & 'dread, fear' & herða (v.) huginn & 'gather one's courage' \\
\hline óttask, v. (3) & 'fear' & hugaðr, adj. & 'courageous' \\
\hline ótti, n. (2) & 'fear, dread' & ofrhugi, n. & 'bravery’ \\
\hline skelfa, n. & 'frighten' & óttalauss, adj. (2) & 'fearless' \\
\hline skelkr, n. & 'fear, fright' & pora, v. (6) & 'have courage' \\
\hline - Cowardice & & - Audacity & \\
\hline ódjarfr (adj.) & 'un-daring' & dirfð, n. (2) & 'daring, boldness' \\
\hline - Anxiety & & djarfliga, adv. (2) & 'daringly, boldly' \\
\hline hafa áhyggju (n.) & 'be anxious, worried' & djarfr, adj. (4) & ‘daring, audacious' \\
\hline ANGER 14 (37) & & TRANQUILLITY 4 (6) & \\
\hline allófrýnn, adj. & 'very sullen, resentful' & hógværr, adj. & 'gentle, meek of mind' \\
\hline allreiðr, adj. (3) & ‘very angry' & kyrrlátr, adj. (2) & 'calm, gentle' \\
\hline heipt, n. (2) & 'fury, spiteful anger' & stilliliga, adv. (2) & 'calmly, composedly' \\
\hline heiptugligr, adj. & 'spiteful, virulent' & stilltr, adj. & 'tempered, composed' \\
\hline
\end{tabular}




\begin{tabular}{|c|c|c|c|}
\hline \multicolumn{2}{|l|}{ Egils saga, negative } & \multicolumn{2}{|l|}{ Egils saga, positive } \\
\hline óblíðr, adj. & 'harsh', lit.: 'un-gentle' & & \\
\hline ófrýnn, adj. & $\begin{array}{l}\text { 'sullen, resentful, } \\
\text { morose' }\end{array}$ & & \\
\hline reiðask, v. (2) & 'become angry' & & \\
\hline reiði,n. (6) & 'anger' & & \\
\hline reiðinn, adj. & 'quick to anger' & & \\
\hline reiðr, adj. (12) & ‘angry' & & \\
\hline snellt, adv. & 'angrily' & & \\
\hline styggliga, adv. & 'angrily, harshly' & & \\
\hline styggr, adj. (4) & 'morose, irritated' & & \\
\hline pykkja, n. & 'anger, resentment' & & \\
\hline CONTEMPT 8 (10) & & LOVE $15(41)$ & \\
\hline allpungr (adj.) til & $\begin{array}{l}\text { 'very unfriendly of } \\
\text { mind' }\end{array}$ & - Love & \\
\hline fátt (adj.) [um] með (2) & 'a strained relationship' & allkærr, adj. (2) & 'very dear, beloved' \\
\hline fjándskapr, n. & 'hostility' & ást, n. & 'love' \\
\hline fjón, n. & 'hostility, hatred' & ástúðigr, adj. & 'loving' \\
\hline $\begin{array}{l}\text { hafa (v.) pungan hug } \\
\text { á (2) }\end{array}$ & 'unfriendly of mind' & ástvinátta, n. & 'intimate friendship' \\
\hline hatask (v.) við & 'hostile towards' & ástvinr, n. & 'beloved, dear friend' \\
\hline úlfúð, n. & 'hostility, enmity' & ávarðr, adj. & 'dear, beloved' \\
\hline \multirow[t]{5}{*}{ vera allilla (adv.) til } & $\begin{array}{l}\text { 'have much antipathy } \\
\text { or dislike' }\end{array}$ & elska, n. & 'love' \\
\hline & & elskr [at], adj. (2) & 'love, be fond of' \\
\hline & & kærleikr, n. (11) & 'love, intimacy' \\
\hline & & kærr, adj. (8) & 'dear, beloved' \\
\hline & & unna, v. (7) & 'love' \\
\hline SURPRISE 1 (3) & & - Affection & \\
\hline \multirow[t]{4}{*}{ undra, v. $(3)^{a}$} & 'wonder' & blíða, n. (2) & 'gentleness, affection' \\
\hline & & blíor, adj. & 'gentle, affectionate' \\
\hline & & blíðskapr, n. & $\begin{array}{l}\text { 'affection, friendly } \\
\text { terms' }\end{array}$ \\
\hline & & finnask (v.) mikit um & 'admire, be fond of' \\
\hline
\end{tabular}

Note

${ }^{a}$ Neither negative nor positive.

beyond that of Egils saga. Overall, this provided 445 instances in which an emotion word is uttered: 250 from Njáls saga and 195 from Egils saga. Seventy-nine different emotion words were extracted from Njáls saga, and eighty-seven were taken from Egils saga. 


\section{Analysis of the lexicon: Egils saga}

Compared to Icelandic novels of the nineteenth and twentieth centuries, the vocabulary of Íslendingasögur is small - the whole corpus of over thirty sagas contains only about twelve thousand and four hundred different headwords, or lexemes, in total (Sverrir Tómasson and Örnólfur Thorsson 1991: 505). ${ }^{11}$ This seems to reflect their "characteristically laconic and economic style" (Pórir Óskarsson 2005: 365). Egils saga is just over sixty-two thousand words long, but the number of individual lexemes is just roughly twenty-eight hundred (Sverrir Tómasson and Örnólfur Thorsson 1991: 504). The eighty-seven emotion words, which are listed in Table 1, form $3.1 \%$ of the sagas' vocabulary. The total count of emotion words in Egils saga (195) is $0.31 \%$ of the total word count in the saga. The words are spread in nine emotion categories: the NEGATIVE categories of SADNESS, FEAR, ANGER, and CONTEMPT; the POSITIVE categories of JOY, COURAGE, TRANQUILLITY, and LOVE; and SURPRISE which includes only a neutral word. Each category (except SURPRISE, which has only one word) includes different nuances of meanings. Fourteen of the eightyseven emotion words only occur in poetry. ${ }^{12}$ In all, in Egils saga, more words communicate positive rather than negative emotions in the ratio of three to two. The biggest categories are LOVE and JOY. In close to half of the cases (42\%) in which an emotion word is uttered in Egils saga, it connotes the positive feelings of either LOVE or JOY. Next comes ANGER, but these three categories are the biggest and are quite similar in size.

\subsection{Royal anger}

One would not characterize Egils saga as having especially joyous or loving themes, as its most prominent categories of emotion words suggest. By examining the most frequent words in the categories of JOY and LOVE, it emerges that, in many instances, the words refer to the emotions of royals and announce their temper, such as their fondness or dislike of

\footnotetext{
${ }^{11}$ Lexemes are the minimal units that form a lexicon. They are the headwords found listed in a dictionary. One lexeme can include different inflections that belong to the same syntactic category.

12 ávarðr 'dear', fjón 'hatred', glaða 'gladden', glaðr 'glad', glýjaðr 'cheerful', heipt 'fury', heiptugligr 'spiteful' or 'virulent', hugaðr 'courageous', óask 'dread' or 'fear', ofrhugi 'bravery', óhryggr 'un-sad', skelfa 'frighten', sorg 'sorrow', and pykkja 'anger' or 'angry resentment'.
} 
their subjects' actions and loyalty. Therefore, many sentences of this type appear:

var konungr allkátr (30)

konungr gladdisk pá (35)

í miklum kærleik við konung (177)

konungr hefir mikla elsku á pér (199) 'the King has much affection for you' 'the King was in very good spirits'

'the King became glad'

'very intimate with the King'

This is also true for the ANGER category, where more than half of the occurrences refer to the king's anger (twenty occurrences out of thirtyseven). The element of the saga that deals with the relationship of Egill and his kin with Norwegian royalty seems to contribute to the number of instances of these emotion word categories..$^{13}$ Ira regis, or royal anger, is a specific display of anger tied to kings, queens, and other royals in the literature and the learned writings of the medieval West (Althoff 1998; White 1998; Barton 1998). In these writings, the king's expression of his anger is portrayed as primarily demonstrative, functioning as a strategic ruling device. As Stephen White argues (1998: 142-43), this involves the king publicly displaying joy and anger alternately, controlling his subjects by giving illustrative signals of his moods. As such, it forms a part of the king's "technology of power" (White 1998: 151).

The demonstration of the king's emotions on these occasions was encoded in "scripts and schemas" that were incorporated into political processes; "it was part of an entire discourse of feuding or retaliatory disputing" (White 1998: 146). Therefore, the expression of just and righteous royal anger was strategic; a ruling practice as well as an illustration of the sovereignty of the king (Barton 1998: 158). Such royal anger appears to be prominent in Egils saga. In more than half of the cases in the ANGER category, the words refer to a king or jarl displaying his anger at certain actions of his subjects, such as the following examples:

konungr var reiðr $(13,29,34)$

bað konung vera eigi reiðan (13) 'the King was angry'

'asked the King not to be angry'

\footnotetext{
${ }^{13}$ Indeed, Egils saga has stylistically much in common with the Old Norse genre of konungasögur (kings' sagas), see, e.g., Ármann Jakobsson (2002); Haukur Porgeirsson (2018).
} 
varð [Eiríkr konungr] reiðr mjǫk (160)

Allreiðr var konungr nú (182)

hafði hann ok fengit reiði konungs (71)

Konungr varð við styggr (13)

varð fyrir reiði Bjarnar Svíakonungs

(182)
'[King Eiríkr] became very angry'

'the King was now very angry'

'he had suffered the King's anger'

'the King fell into a bad temper'

'suffered the anger of Bjorn, King of Swedes'

A representative example is the following account in Egils saga that tells of the disputes between Pórólfr Kveld-Úlfsson and King Haraldr lúfa of Norway in Chapters 11-22. These chapters tell of how the sons of Hildiríðr surely and steadily succeed in defaming Pórólfr to the King and convince him that Pórólfr aspires to surpass him and perhaps overthrow him. In the beginning, Pórólfr is close to King Haraldr, who has given Pórólfr the title of a landholder (24). However, the King becomes angry when Pórólfr surpasses him in the number of followers at a feast. The King's displeasure at this is displayed by him becoming "ókátr" (29) 'cheerless' and he turns red, falls silent, and men could feel that he was angry (29). Pórólfr soothes the King with appeasing talk and the gift of a great ship. The King's mood turns mild and cheerful at this (29). Next, it is noted that King Haraldr sits in very good spirits (30) at a feast. There, the sons of Hildiríor tell him that Pórólfr plans to betray him. The King "reiddisk mjok" (32), 'became very angry', but he simultaneously is pleased with the gifts that the sons of Hildirior brought him. But at the mention of Pórólfr's name, the King demonstrates his anger so that he "svarar engu, ok sáu menn, at hann var reiðr” (34), 'answers nothing, and people could see that he was angry'. Pórólfr counteracts by giving him beaver skins and other treasures, and the King's mood turns, he becomes glad and is willing to listen to Pórólfr's point of view (35). Nevertheless, Pórólfr is defamed again, and King Haraldr becomes "inn reiðasti” (38), 'most angry', yet again. Pórólfr consults with his friends, and they discuss how the King's mood might be turning (38). Subsequently, Pórólfr attempts to appease Haraldr with gifts and reassurance but to no avail. Haraldr demands full surrender, which Pórólfr is not willing to provide. The affair concludes with Haraldr slaying Pórólfr in battle (54).

Throughout the whole account, the swinging mood of King Haraldr is central, and it is carefully noted what actions arouse his anger and how 
his subjects try to appease it. The King's anger has a clear demonstrative feature: it is displayed vividly in public by reddening and not speaking, and it is noted in the text that the men could see that the King was angry. In these scenes, King Haraldr alternates in a script-like way between displaying anger and joy as a strategic ruling device as fits his political aim of controlling his subjects and maintaining his power. Similar examples of royal anger appear throughout Egils saga. This narrative device results in the prominence of words connoting anger, joy, and love in the saga's lexicon of emotion words; most cases are tied to this element of strategic royal "technology of power" (White 1998: 151).

\subsection{Formulas}

It is thus evident that the frequent appearance of words denoting anger in Egils saga are part of a narrative formula involving royal anger. Íslendingasögur are characterized by many formulaic locutions when people and events are described, and indeed formulas have been noted as "a typical feature of saga style" (Sävborg 2017: 115). Many repeated scenes and situations have their own particular formula. Thus, in the corpus, concerning how characters are introduced, well over one hundred examples exist of men entering the saga described as miklir ok sterkir 'great and strong' (Sverrir Tómasson and Örnólfur Thorsson 1991: 505$6)$.

Such formulas are narrative constructions that signal to the audience how to understand what they read or hear. Thus, as Daniel Sävborg argues, they function by "arousing the expectation of the audience or reader", and they "are loaded with meaning necessary for the interpretation of the events, characters, and plot" (Sävborg 2017: 118). For example, Sävborg identifies repeated formulas that express amorous feelings through behaviour, such as when a man and a woman sit and converse, visit frequently and give gifts (Sävborg 2007: 45-67).

In Egils saga, $76 \%$ of the emotion words in the lexicon above are only used once or twice. The other $24 \%$ that are used more often are frequently a part of a formula, such as is applied in the case of royal anger. Another example is how almost exclusively and repeatedly the words feginn 'glad, joyful', allfeginn 'very joyful', feginsamliga 'gladly' or 'joyfully', and allfeginsamliga 'very joyfully' are used when someone is received upon return from somewhere, in sentences of this type: 
$\begin{array}{ll}\text { Tók hann við peim allfeginsamliga (19) } & \text { 'he received them very joyfully' } \\ \text { tók hann við honum feginsamliga (81) } & \text { 'he received him joyfully' } \\ \text { tók hann feginsamlega við peim (92) } & \text { 'he received them joyfully' } \\ \text { tekit við honum vel ok feginsamliga (174) } & \text { 'received him well and joyfully' } \\ \text { tók Pórir feginsamliga við konungssyni } & \text { 'Pórir received the King's son } \\ \text { (166) } & \text { joyfully' }\end{array}$

The same applies to the formula of men repeatedly being allkátir 'very joyful' when feasting and drinking (Egils saga 1933: 115-16, 121, 125) and being in karleikar 'affection' or 'intimacy' when describing a good, secure relationship with a royal:

komsk hann í ina mestu kærleika við konung (10)

'he became very intimate with the King'

í allmiklum kærleikum af konungi (20)

'very intimate with the King'

skilðusk pá með kærleik miklum (29) 'they departed with much intimacy'

í miklum kærleik við konunginn (177)

'in much intimacy with the King'

Pórir var pá í inum mestum kærleikum við konung (90)

'Pórir was then in the most intimacy with the King'

The other part - the $76 \%$ of the lexicon only used once or twice - are words applied in a specific context in a purposeful, precise way. A good example of how this is done is in relation to Egill's son, Porsteinn, who is at the centre of the saga in the last ten chapters. Porsteinn is baptized as a Christian when the new faith arrives in Iceland and builds a church at Borg (Egils saga 1933: 299) whereas Egill remains a heathen his whole life. ${ }^{14}$ Egill has grown old and decrepit and can be seen as representing the past ways at this point in the saga, a pagan culture that is in many ways coming to an end. This is underlined by emphasizing Porsteinn as Egill's successor in the last chapters of the saga and how different the two are in their emotional character, as well as the contrast between the two strands of dark and bright appearance that run in the family. In most ways,

\footnotetext{
${ }^{14}$ At King Aðalsteinn's request, Egill gets primsignaðr (takes the sign of the cross) to be able to interact with Christians. Those who did so kept their faith and were not turning to Christianity (Egils saga 1933: 128-29).
} 
Porsteinn is the emotional antithesis of his father. The narrator describes Porsteinn as "órefjusamr ok réttlátr ok óáleitinn við menn" (Egils saga 1933: 293), 'un-deceitful, just and unobtrusive'. While the dark Egill is notorious for his extreme temper, all the emotion words in the category TRANQUILLITY refer to Porsteinn: hógvaerr 'gentle', kyrrlátr 'calm', stilltr 'tempered', and stilliliga 'composedly' $(274,277,274)$. In addition to being blond, beautiful, wise, and strong (274), Porsteinn's disposition can be illustrated with reference to what Bandlien has described as the Christian ideal of "rational, tempered and civilized" masculinity (Bandlien 2005: 164), whereas Egill rather conforms to the Old Norse "aggressive masculine ethic" (Meulengracht Sørensen 1983: 21). The differences in the choice of words used to describe the emotions of the father Egill and his son Porsteinn reflect how specifically the emotion words are applied in the saga, a point further illustrated in other themes, such as gender and poetic language, to which I turn next.

\subsection{Gender differences and Ásgerðr Bjơrnsdóttir}

Egils saga is almost void of emotion words about women's feelings. A woman's emotion is only mentioned eleven times in the saga out of the 195 occurrences. Five of those cases concern Queen Gunnhildr's royal feelings of like or dislike ${ }^{15}$ and can be viewed in the same light as the examples above on royal anger. Porgerðr's feelings are noted once from the mouth of her father Egill: "mikla ást hefir pú sýnt við mik" (244-45), 'you have demonstrated much love towards me', and three examples concern minor female characters that briefly enter the saga: djarfr, ókátr, feginn $(85,201,230)$ 'daring, unhappy, joyful'. Lastly, the feelings of Ásgerðr Bjornsdóttir are noted twice with the words ókátr and unna (148, 274) 'unhappy, love'. The latter concerns the occasion during which it is noted that much love exists between her and her son Porsteinn, whereas Egill does not love his son much: "Egill unni honum lítit; Porsteinn var ok ekki við hann ástúðigr, en pau Ásgerðr ok Porsteinn unnusk mikit.” (274), 'Egill loved him little; Porsteinn was likewise not loving towards him, but Ásgerðr and Porsteinn loved each other very much'.

This is the only example from the saga where so many emotion words (three) are found in the same sentence. Yet, this brief account is a fine

\footnotetext{
${ }^{15}$ These are karleikr 'intimacy', Egils saga 1933: 94; karr 'dear', 106, 123, 152; allpungr til 'very unfriendly of mind towards', 150.
} 
example of the emotive style of the saga. In just a handful of words, a tense and dramatic family situation is laid out, where the cold contempt between father and son is contrasted with much love and affection between the son and his mother. The scene also reverberates the strained relationship between Egill and his own father, Skalla-Grímr, who tried to kill him as a child and subsequently did not speak to him for a whole winter (101-2). ${ }^{16}$

The other time that Ásgerðr's feelings are noted is when Egill tells her that his brother Pórólfr, her husband, is dead. Egill has probably loved Ásgerðr since they were adolescents, ${ }^{17}$ and he now offers her his care, perhaps insinuating or suggesting that they marry. Her response is very obscure: “Ásgerðr varð mjokk ókát við pá soggu, en svaraði vel rœðum Egils ok tók lítit af ollu” (148), "Ásgerðr became very unhappy at hearing this, she answered Egill's words politely but gave little and indefinite answers.' Egill reacts to her moot response by falling into a deep melancholy and lastly confides in his best friend Arinbjorn how much he loves her. As the object of Egill's love, Ásgerðr is one of the central figures in the saga, and Egill's strong feelings towards her have decisive effects on how the narrative unfolds (see, e.g., Torfi $\mathrm{H}$. Tulinius 2004: 50-51). How Ásgerðr feels about him, however, remains rather hidden. When Egill finally gathers the courage to ask her to marry him, she does not disclose her will but simply dutifully refers the matter twice to her father and uncle to decide (150). The matter is finally concluded by Egill betrothing Ásgerðr. The fact that Ásgerðr does not express approval when repeatedly given the chance can be taken to indicate that she is not too keen on marrying Egill, but she does not assert opposition to it either, although her moot responses might consist of a statement thereof. Within the narrative, Ásgerðr's figure functions as the focus of Egill's desire, but she is, herself, almost invisible. She does not have an opinion or a voice. She is never given direct speech in the entire saga, and her feelings are implied only in relation to Egill's reactions to them. In this sense, she plays a narrative role similar to that of many idealized ladies in the courtly romances: her persona exists only in the form of a passive object of Egill's desire.

\footnotetext{
${ }^{16}$ Ármann Jakobsson (2008) writes about the tense relationship between Egill and his father.

${ }^{17}$ On the early onset of Egill's love for Ásgerðr, see Torfi H. Tulinius (2004: 50-51); Bredsdorff (2001: 23-34).
} 


\subsection{The speaker and the poetic voice}

The speaker of the emotion words in Egils saga is most often the narrator, or in two-thirds of the cases. Most frequently, the narrator is noting the feelings of royals (forty-two instances) or Egill (twenty-eight instances). As has been pointed out, the external focalization of the narrative voice in the genre of Íslendingasögur means that the characters' inner emotional processes are rarely analysed in the prose (Sävborg 2017: 123; Sif Rikhardsdottir 2017: 57; Miller 1992: 94-97). It should nevertheless be observed that multiple examples in this lexicon exist where the narrator does have access to the inner lives of the characters and communicates how they feel, as the following samples demonstrate:

\begin{tabular}{|c|c|}
\hline Kveld-Úlfr [varð] hryggr (60) & 'Kveld-Úlfr [...] became mournful' \\
\hline herði [Egill] pá huginn (178) & '[Egill] then plucked up his courage' \\
\hline $\begin{array}{l}\text { Skalla-Grímr varð við pat allglaðr } \\
\text { (87) }\end{array}$ & $\begin{array}{l}\text { 'Skalla-Grímr became very glad at } \\
\text { that' }\end{array}$ \\
\hline gerðisk Egill pá enn einteiti (216) & 'Egill turned to a very good mood' \\
\hline $\begin{array}{l}\text { unni honum ok vel faðir ok móðir } \\
\text { (80) }\end{array}$ & $\begin{array}{l}\text { 'his father and mother loved him } \\
\text { much' }\end{array}$ \\
\hline Egill unni honum mikit (243) & 'Egill loved him much' \\
\hline $\begin{array}{l}\text { var Pórólfr allókátr ok svá Arinbjorn } \\
\text { (113) }\end{array}$ & $\begin{array}{l}\text { 'Pórólfr was very unhappy, as was } \\
\text { Arinbjǫrn' }\end{array}$ \\
\hline
\end{tabular}

Here, the narrator appears omniscient, describing in direct words how characters feel and telling the audience that they are angry, sad, mournful, striving for courage, glad, merry, or in love. However, the feelings are not analysed or commented on further. The instances are brief, quick, and usually contain only one emotion word, occasionally two, but only once contain three.

When emotion words are uttered by a character in Egils saga, it is most often not about the character's own feelings but about the feelings of others (in two-thirds of the cases). Representative examples include Egill's question to a young woman: "Hvat grætr pú, mær? Ek sé pik aldri káta" (201), 'What are you crying over, young girl? I never see you cheerful', and his words to his daughter: "mikla ást hefir pú sýnt við mik" (244-45), 'you have shown me much love'.

Out of the 195 instances in which an emotion word is uttered in the 
saga, only twenty-tree apply to characters expressing their own feelings. The data thus conform to the general finding that characters in Íslendingasögur "rarely express their emotions themselves" (Sävborg 2017: 118). In accordance with Egill's centrality in the saga, in eighteen of those twenty-three cases, it is Egill who is speaking about his own emotions. A clear difference exists here between the prose and the poetry. Egill's selfexpression of emotions mainly occurs in his poems. Out of the eighteen instances, fifteen occur in his poetry: $:^{18}$

\begin{tabular}{|c|c|c|}
\hline ástvinr, $\mathrm{n}$. & 'beloved' & Sonatorrek 7 (248) \\
\hline glaðr, adj. & 'glad' & Sonatorrek 25 (256) \\
\hline gleðja, v. & 'gladden' & Lausavísa 5 (82) \\
\hline harmr, n. (3) & 'grief' & Lausavisur 17, 20, $59(142,145,295)$ \\
\hline heipt, n. (2) & 'fury' & Lausavísur 31, $50(170,269)$ \\
\hline óhryggr, adj. & 'un-grieved' & Sonatorrek 25 (256) \\
\hline reiði, $\mathrm{n}$. & 'anger' & Lausavísa 14 (121) \\
\hline sorg, $\mathrm{n}$. & 'sorrow' & Lausavísa 24 (149) \\
\hline undra, v. & 'wonder' & Lausavísa 57 (293) \\
\hline pora, v. (2) & 'have courage' & Arinbjarnarkv. 6 (259), Lausavísa 23 (148 \\
\hline pykkja, n. & 'angry resentment' & Lausavísa $47(228)^{19}$ \\
\hline
\end{tabular}

Skaldic poetry in the sagas has been shown to convey feelings, such as love and grief, more openly and in a more detailed way than is done in the prose, and the speakers analyse and describe their own emotions to a higher degree than in the prose (Sävborg 2007: 275-76; Sif Rikhardsdottir 2017: 85-97). However, while a statistical analysis such as this one confirms that self-expression of feelings occurs to a higher degree within the poetry than the prose, the use of emotion words comprises only a very small part of the conveyance of feelings in the poetry. The kennings and

\footnotetext{
${ }^{18}$ The three instances from the prose are "Hver ván er, at ek muna lifa vilja við harm penna?" (254), 'How can I be expected to want to live with such grief?'; “Hræðumk ek bjorninn" (167), 'I am afraid of the bear'; "áhyggjur hefi ek miklar" (214), 'I have great worries'.

19 "pykkiar" in Möðruvallabók, "pickjo" in Ketilsbók (AM 462 4to), which supports the emendation to "bykkja" 'angry resentment' in Egils saga (1992: 181) which I consider most likely to be correct. However, it is amended to "pykkjumsk" in Egils saga (1933: 228), which gives the meaning "I regard".
} 
other kinds of circumlocutions in the poems attributed to Egill, metaphors, rhythm, poetic language, and emotive themes that sometimes run through a whole poem, such as Sonatorrek, as well as the interaction of the poem with the prose, all work to intensify the emotive force of what is being expressed. These forcefully convey feelings in an artistic manner outside the narrow semantic scope of emotion words.

\section{Analysis of the lexicon: Njáls saga ${ }^{20}$}

Njáls saga is about one hundred thousand words long, but the number of individual words or lexemes is just roughly thirty-one hundred (Svanhildur Óskarsdóttir 1991: xvi). Of these lexemes, 2.5\% (seventy-nine) are emotion words, shown below in Table 2. The total count of emotion words in Njáls saga (250) is $0.25 \%$ of the total word count in the saga. The biggest category is ANGER. Words connoting this feeling are mentioned in $22 \%$ of all instances in which an emotion is named in the saga. Next comes FEAR (19\% occurrence). Njáls saga also has categories that Egils saga does not have: ENVY and being TAKEN ABACK (a sub-category of SURPRISE). Both are from the overarching NEGATIVE category. Overall, more occurrences of words communicate negative emotions in Njáls saga, with the ratio of three to two.

\subsection{The speaker}

Turning first to the speakers of the words, the data show that emotion words coming from the mouth of a character are more frequent in Njáls saga than Egils saga, or in roughly half of the cases an emotion word is uttered in the saga (compared to one-third in Egils saga). In fact, Njáls saga contains double the proportion of direct speech compared to Egils saga, as Peter Hallberg (1966) has demonstrated, and also that Njáls saga has the highest percentage (at $41 \%$ of the text) of direct speech of all the longer sagas (Hallberg 1966: 130).

\footnotetext{
${ }^{20}$ The lexicon includes words from poetry not included in the main text of the Svart á hvítu or Íslenzk fornrit editions, but which is published in an appendix in the latter. These are four words, óttlauss 'fearless' (Brennu-Njáls saga 1954: 468), djarfr 'bold' (471), hrceðask 'be afraid of' (477), and reiðr 'angry' (479), all from stanzas included in either Reykjabók or Kálfalækjarbók (AM 133 fol.).
} 
Tab. 2. Words referring to an emotional state in Njáls saga. Numbers following each heading in the table refer to how many words are in the category. Numbers in parenthesis refer to the frequency. The absence of a number indicates the words occurs only once.

\begin{tabular}{|c|c|c|c|}
\hline Njáls saga, negative & & Njáls saga, positive & \\
\hline SADNESS 11 (21) & & JOY 9 (26) & \\
\hline dapr, adj. & 'sad' & allkátr, adj. & 'very cheerful, happy' \\
\hline harma, v. (3) & 'mourn' & feginn, adj. (13) & 'glad, joyful' \\
\hline harmdauði, adj. (3) & 'mourned' & glaðr, adj. (3) & 'glad' \\
\hline harmr, n. (3) & 'grief' & gleðja, v. & 'gladden, enliven' \\
\hline harmsǫk, n. (2) & 'cause of grief' & gleðibragð, n. & 'merry looking' \\
\hline hugsjúkr, adj. & $\begin{array}{l}\text { 'depressed', lit. 'mind- } \\
\text { sick' }\end{array}$ & hlœgja, v. (2) & 'exhilarate, cheer up' \\
\hline hǫrmuligr, adj. & 'tragic, sad' & kátligr, adj. & 'cheerful' \\
\hline skappungt, adj. (4) & 'of heavy mind' & kátr, adj. (3) & 'cheerful, happy’ \\
\hline syrgja, v. & 'mourn, grieve over' & léttr, adj. & 'cheerful' \\
\hline tregi, $\mathrm{n}$. & 'sorrow' & & \\
\hline pykkja (v.) fyrir & $\begin{array}{l}\text { 'saddened, regretful, } \\
\text { sorry' }\end{array}$ & & \\
\hline FEAR $14(48)$ & & COURAGE 8 (30) & \\
\hline - Fear & & - Bravery & \\
\hline felmta, v. & 'be afraid' & allóhræddr, adj. & 'very un-afraid' \\
\hline hræðask, v. (13) & 'be afraid of, fear' & hugaðr, adj. & 'courageous' \\
\hline hræddr, adj. (11) & 'afraid' & ofrhugi, n. (2) & 'fearless man' \\
\hline hræðsla, n. (3) & 'fear' & óttlauss, adj. & 'fearless' \\
\hline óttafullr, adj. (1) & 'full of fear' & pora, v. (20) & 'have courage' \\
\hline óttask, v. (2) & 'fear' & óhræddr, adj. (2) & 'un-afraid' \\
\hline ótti, n. (3) & 'fear, dread' & - Audacity & \\
\hline æðra, n. (2) & 'fear, despair' & djarfliga, adv. (2) & 'daringly, boldly' \\
\hline - Cowardice & & djarfr, adj. & 'bold, daring' \\
\hline argr, adj. & 'cowardly' & & \\
\hline blauðr, adj. (3) & 'cowardly' & & \\
\hline huglauss, adj. & 'cowardly' & & \\
\hline hugleysi, n. & 'cowardice' & & \\
\hline ragr, adj. (5) & 'cowardly, fainthearted' & & \\
\hline \multicolumn{4}{|l|}{ Anxiety } \\
\hline áhyggja, n. & ‘anxiety, worry' & & \\
\hline ANGER $12(54)$ & & TRANQUILLITY 5 (12) & \\
\hline allreiðr, adj. & 'very angry' & hógværr, adj. (2) & 'gentle, meek of mind' \\
\hline beiskr, adj. & $\begin{array}{l}\text { 'embittered, } \\
\text { acrimonious' }\end{array}$ & orðstillttr, adj. & 'moderate in words' \\
\hline bráđr, adj. & 'quick-tempered' & skapgóðr, adj. & 'good-tempered' \\
\hline
\end{tabular}




\begin{tabular}{|c|c|c|c|}
\hline Njáls saga, negative & & Njáls saga, positive & \\
\hline geisa, v. (2) & 'rage' & stilla (v.) sig & 'temper oneself' \\
\hline reiðask, v. (10) & 'become angry' & stilltr, adj. (7) & 'tempered, composed' \\
\hline reiði,n. (11) & 'anger' & & \\
\hline reiðr, adj. (22) & 'angry' & & \\
\hline síreiðr, adj. & 'always angry' & & \\
\hline skapbráđr, adj. & 'hot-tempered' & & \\
\hline styggr, adj. (2) & 'morose, irritated' & & \\
\hline vera (v.) mikit í skapi & 'be very upset' & & \\
\hline œði (n.) mikil & 'much rage, fury' & & \\
\hline CONTEMPT 6 (13) & & LOVE $9(30)$ & \\
\hline fáleikr, n. (3) & 'strained/cold relation' & - Love & \\
\hline mislíka, v. (2) & 'dislike, resent' & ást, n. (2) & 'love' \\
\hline ópokki, n. (3) & 'animosity, hostility' & elskr, adj. & 'love, be fond of' \\
\hline ópykkt, n. & $\begin{array}{l}\text { 'ill-will, dislike, } \\
\text { discord' }\end{array}$ & kærleikr, n. & 'love, intimacy' \\
\hline fátt (adj.) um með (3) & 'strained relationship' & kærr, adj. (2) & 'dear, beloved' \\
\hline \multirow[t]{2}{*}{ vera illa (adv.) til } & $\begin{array}{l}\text { 'have antipathy or } \\
\text { dislike' }\end{array}$ & unna, v. (10) & 'love' \\
\hline & & leggja (v.) hug á (3) & 'be in love with' \\
\hline ENVY $2(6)$ & & Affection & \\
\hline Qfunda, v. (5) & 'envy' & blíða, n. (2) & 'gentleness, affection' \\
\hline \multirow[t]{2}{*}{ ofundarmaðr, n. } & 'one who envies' & blíðliga, adv. (4) & 'affectionately, gently' \\
\hline & & blíðr, adj. (5) & 'gentle, affectionate' \\
\hline \multicolumn{4}{|l|}{ SURPRISE 3 (10) } \\
\hline \multicolumn{4}{|l|}{ - shocked/taken aback } \\
\hline bregða (v.) í brún (2) & 'shocked, taken aback' & & \\
\hline bregða (v.) við (6) & 'shocked, taken aback' & & \\
\hline \multicolumn{4}{|l|}{ - wonder ${ }^{\mathrm{a}}$} \\
\hline undra, v. (2) & 'wonder' & & \\
\hline
\end{tabular}

Note

${ }^{\mathrm{a}}$ Neither negative nor positive.

Even though emotion words are often spoken by the characters in Njáls saga, they are usually not referring to their own feelings but those of others. In only about one-third of the instances in which a character speaks an emotion word, it concerns his or her own inner state (forty-two instances, of which five occur in poetry). These are spoken by twenty different characters, most often Gunnarr and Skarpheðinn (six times each), communicating their own fearlessness or anger. 
However, the few cases of self-expression include famous and muchquoted sentences, such as Gunnar saying "mér pykkir meira fyrir en oðrum mǫnnum at vega menn" (Brennu-Njáls saga 1954: 139), "the slaying of men saddens me more than other men', and Njáll saying "ek unna meira Hǫskuldi en sonum mínum, ok er ek spurða at hann var veginn, pótti mér sløkkt it sœtasta ljós augna minna" (309), 'I loved Hoskuldr more than any of my sons, and when I learned that he had been slayed, I felt like the dearest light of my eyes had been put out'. In Njáll's emotive speech, there is a rare elaboration and reiteration of an emotional state: "pat er sannligt at segja, at svá fellr mér nær um trega, at mér pœtti betra at hafa látit tvá sonu mína ok væri Hǫskuldr á lífi” (281), "it is true that I am so deeply stricken by grief, that I would think it better to have lost two of my sons and Hoskuldr was still alive'. Njáll's grief is dwelt on here more than is done in any scene found in the prose of Egils saga. As Vésteinn Ólason points out (1998: 114), such unrestrained emotional talk "is unusual and unquestionably reflects the influence of religious literature" on Njáls saga.

When it comes to the narrative voice, however, it does not analyse the characters' inner lives with words but, nevertheless, has access to their psyche as in the following representative examples:

Hon unni honum mikit ok mátti eigi stilla sik ok grét hástǫum. (48)

var brúðrin dọpr heldr. (22)

Gunnarr varð glaðr við pat. (77)

Hann oqundaði mjǫk Gunnar frá

Hlíðarenda. (119)
'She loved him much and could not contain herself and cried loudly.'

'the bride was rather sad.'

'Gunnarr became glad at this.'

'He envied Gunnarr from Hlíðarendi much.'

Here, the narrator describes how characters feel in a direct way through emotional language. However, the feelings are not commented on further. The instances are brief, quick, and most often contain only one or two emotion words. In this way, the use of emotion words is similar to that in Egils saga, although with notable deviances concerning Njáll's speech.

\subsection{Gunnarr and the application of royal anger}

Njáls saga does not concern itself much with the interaction of its main characters with kings and other royalty. However, examples of royal anger appear in Chapter 88 of the saga, when Práinn Sigfússon hides an escaped 
offender aboard his ship. This is the only scene in the saga that includes instances of royal anger in line with those that are described above, occurring in Egils saga. The escapee, Hrappr, has burnt Jarl Hákon's temple to the ground and killed some of his men. The Jarl repeatedly boards Práinn's ship and searches for Hrappr, each time to no avail. In each instance, the Jarl displays his anger and, for example, becomes on one occasion "svá reiðr, at ekki mátti við hann mæla" (219), 'becomes so angry, that it was not possible to speak to him'. When Práinn flatly denies having hidden Hrappr aboard his ship, Hákon does not resort to violence but coldly notes: "heldr vil ek, at pú níðisk á mér en ek á pér." (220), 'I would rather have that you behave shamefully towards me than I towards you'. Thus, it is stressed in the scene that it is honourable for a noble man like Hákon to show restraint, while it is also made clear that his mere display of anger arouses fear in his subjects. But even though Jarl Hákon's noble anger is noted many times in this particular scene, no one's anger is mentioned more often in the saga than Gunnarr Hámundarson's, or in $21 \%$ of the cases the words reiðask 'become angry', reiði 'anger', and reiðr 'anger' are used.

Gunnarr is not royal by blood. However, several methods are used in the saga to allude to his aristocratic and knightly image. When he is introduced, the description is that of a sublime noble hero. Apart from his beautiful appearance, ruddy cheeks and golden hair, he is described as big and strong and the most skilled of all men in battle (53).

Hann skaut manna bezt af boga ok hœfði allt pat, er hann skaut til; hann hljóp meir en hæð sína með ọllum herklæðum, ok eigi skemmra aptr en fram fyrir sik; hann var syndr sem selur, ok eigi var sá leikr, at nokkurr byrfti við hann at keppa, ok hefir svá verit sagt, at engi væri hans jafningi. [...] Manna kurteisastr var hann. (53).

(He shot from a bow better than anyone, and he never missed his mark. He jumped higher than his own height in full armour, and no less backwards than forwards. He could swim like a seal, and there was no game in which there was any point in competing with him, and it has been said that no man was his equal. [...] He was the most courteous of men.)

The word kurteiss 'courteous', used to describe Gunnarr, came into Old Norse through translated romances in the thirteenth century, and the description of Gunnarr includes many features of a courteous knight. Among the traits that define Gunnarr are his superior skills in archery. Archery is described as the noblest sport, hofðingligr, in the konungasögur compilation Heimskringla (1991: 734) but is not common in other genres of Old Norse sagas. 
Additionally, apart from Gunnarr's superhuman physical qualities, gorgeous looks, and extravagant clothes $(82-83,85,150)$, he possesses a magical weapon (80-81) and an animal companion, an Irish royal dog called Sámr who has the intelligence of a man $(173,186)$. The dog is a gift from the grandson of King Myrkjartan of Ireland. This aligns Gunnarr with the noble heroes of the romances, such as the knight Yvain in Chrétien de Troyes' Yvain (le Chevalier au lion), who had a lion by his side. ${ }^{21}$ Much in the same way as the relationship between the lion and Yvain, Sámr can be viewed as a mirror of Gunnarr's psyche, an animal extension of his noble character. Their lives are entwined, for Gunnarr cannot be attacked in his home while the dog lives, as his enemies remark (174). The death of one signals the death of the other.

Such is also the case in the konungasaga of King Óláfr Tryggvason. When the King Óláfr's dog, Vígi, hears of the death of his master, he howls loudly and falls dead as tears fall from his eyes and down his snout (Óláfs saga Tryggvasonar en mesta 1958-2000, II: 299). Accordingly, Gunnarr's enemies need to kill Sámr to reach Gunnarr. They slay the dog with an axe-blow through his skull to his brain - a death that resonates more with descriptions of battles between men rather than an animal being put to death (186). When Sámr is killed, the loudness of his howl is unheard of, and when Gunnarr hears it, it signals for him his own death: "Sárt ertú leikinn, Sámr fóstri, ok búo svá sé til ætlat, at skammt skyli okkar í meðal” (186), 'You have been sorely treated, my fosterling Sámr, and it is to be expected that it is meant to be so that our deaths will not be far apart'. These knightly connotations serve to underline the noble features of Gunnarr further.

The display and mentions of Gunnarr's anger function in the saga as a strategic ruling device. People in the saga who are subordinate to Gunnarr seek to avoid his anger, and when he displays it, they become afraid and do as Gunnarr wishes. Práinn Sigfússon refuses to kill Pórðr leysingjason because he does not want to suffer Gunnarr's anger: "Eigi mun ek pat gera [...] pví at pá mun ek hafa reiði Gunnars" (107), 'I will not do that [...] because then I will have Gunnarr's anger'. In other cases, Gunnarr displays his anger as a threat, such as when he overhears the members of his household recite slanderous poetry, ridiculing his friend and closest ally, Njáll, for lacking a beard. The people are laughing loudly when Gunnarr abruptly enters the room:

${ }^{21}$ On the narrative function of the lion in Yvain, see Hunt (1983). 
Qllum brá við mjǫk, er hann sá inn ganga; pognuðu pá allir, en áđr hafði par verit hlátr mikill. Gunnarr var reiðr mjǫk [...] „ef nọkurr maðr hermir pessi orð, pá skal sá í brautu verða ok hafa pó reiði mína." En svá stóð peim af honum mikil ógn, at engi porði pessi orð at herma. Síðan gekk hann í braut. (113)

(They were all very taken aback when they saw him enter the room; they all fell silent, but before, there had been much laughter. Gunnarr was very angry [...] "anybody who repeats these words shall be expelled from here and still have my anger." They were so intimidated by him that no one dared to repeat the words. Then he walked away.)

Here, Gunnarr does not threaten physical violence with bare words but threatens something that seems to be much more influential: that anyone acting against his decree "will have his anger". The people, including his wife, become so afraid that they do not dare to contradict his will. The pattern that emerges is that Gunnarr's anger is displayed in a noble, royal way. His anger functions in a demonstrative manner, as a ruling device, illustrating his power, and it follows the same script as ira regis, royal anger.

The frequent mention of Gunnarr's anger might seem to be in contrast to the description of him as "stilltr vel" (53), 'even-tempered', as well as numerous accounts of him showing restraint and temperance when provoked by his wife Hallgerðr and others $(151,94,98,106,117-18,121-$ $22,180)$. The key element here is the control he has over his reactions. As Hildigunnr Starkaðardóttir remarks: “Gunnarr er seinpreyttr til vandræða, en harðdrœgr, ef hann má eigi undan komask” (149), 'Gunnarr is slow to be aroused to hostilities, but hard-hitting if he cannot avoid them'. It is clearly indicated that Gunnarr does not act in haste and his displays of anger are always portrayed as just: only when his patience, mildness, and temperance have been seriously tried through many provocations by his enemies and he is accused of the effeminizing act of crying (135), does he draw the line, become severely angry, and avenges by blood. A fundamental element in the honourable practice of anger is that retribution is conducted justly and in a controlled manner (see Althoff 1998). As Gunnarr prepares for a slaying in revenge, his anger is unfamiliar to his mother, who remarks that she has never seen him look so angry before (136). When Gunnarr returns from the successful vengeance, his friend Njáll implies that Gunnarr has been extremely patient in the events leading up to this and that his reactions are excusable: "hefir pú verit mjok at preyttr" (139), 'you have been severely tried'. Njáll thus describes Gunnarr's anger as righteous and his actions justified. In this 
way, Gunnarr's expression of his anger is in alignment with the emotive script of just royal anger, which serves to situate his character within the noble realm.

\subsection{Gender differences}

In Njáls saga, particular words are repeatedly tied to the same action, such as where it is noted with a formulaic wording that a male gets angry and subsequently insults someone, or more commonly, strikes a blow (Brennu-Njáls saga 1954):

Pá reiddisk Họskuldr, ok var fátt um með peim brœðrum (7)

Pá reiddisk Hǫskuldr ok laust sveininn með sprota [...] sprotinn kom í andlitit, ok sprakk fyrir (29)

Pá reiddisk Porvaldr ok laust hana í andlitit, svá at blœddi (33)

Pá reiddisk Glúmr ok hjó til hans með handsaxi (49)

Gunnarr reiddisk ok mælti: „Illa er pá, ef ek em pjófsnautr“, - ok lýstr hana kinnhest. (124)

Porkell spratt pá upp af mikilli reiði og greip sax sitt [...] ,,skal ek reka saxit í gegnum pik“ (305)
'Then Hǫskuldr became angry, and the relationship between the brothers was strained'

'Then Hoskuldr became angry and struck the boy with a stick [...] the stick hit his face and cut through the skin'

'Then Porvaldr became angry and hit her in the face so it bled'

'Then Glúmr became angry and struck at him with a short sword'

'Gunnarr became angry and said: "It is bad if I am a thief's partner" and slapped her on the cheek.'

'Porkell sprung up with much anger and grabbed his short sword [...] "I will thrust this short sword through you"،

The formula above is only applied to one woman, Pórhildr skáldkona. She catches her husband gazing at a young woman. Her following actions are not a physical slap or a blow, but a verbal one in the form of a couplet:

hon reiðisk ok kveðr til hans kviðling:

„Era gapriplar góðir, gægr er pér í augum,

Práinn“, segir hon. (89)

'she becomes angry and recites a couplet: "The [or: Your] gaping rods are no good, I lechery is in your eyes, I Práinn,” she says.' 
The latter element in gapripill (ripill) can be read as a metaphor for a small penis. ${ }^{22}$ This would provide the meaning that Práinn's "small gaping penis is dysfunctional", which is certainly a great attack on Práinn's manhood. By reciting the couplet, Pórhildr retaliates the disgrace her husband showed her with the power that is available to her - the equivalent of slapping. Her words are such an insult that her husband's reaction is swift, swifter than in any of the other cases where this formula is applied. Práinn immediately throws Pórhildr out of the house, announces their divorce, and replaces her with the young woman he was gazing at. Pórhildr is severely reprimanded for her display of anger, the scene not only marks her exit from the house and her marriage but also from the saga. However, while the account of Pórhildr's fate unfolds in the above manner in the saga text, the outcome of the plot on another narrative level is considerably in Pórhildr's favour: With the insult being in verse, it adheres to the tale of the events to Práinn's shame, and the saga's subsequent portrayal of him is less than favourable. ${ }^{23}$

The case of Pórhildr's anger is one of the few instances in which the feelings of a woman are expressed with an emotion word in Njáls saga. That only occurs twenty-four times. ${ }^{24}$ Two aspects are most noteworthy about the use of words regarding women's emotions: the gender difference in the use of words connoting anger and the depiction of Hallgerðr Hǫskuldsdóttir's emotions.

\subsection{Words for female anger}

Slightly different words are used for the emotions of women and men. Both genders are blidr 'tender, affectionate' and feginn 'joyful', and both

\footnotetext{
${ }^{22}$ Ripill here has the meaning a "thin rod", see "ripill” in Íslensk orðabók (Mörður Árnason 2007). The compound word Hafalda-ripill refers to an object used in weaving for the purpose of binding loops (literally "loop-rod"), see Matthías Pórðarson (1914: 17). This creates a reference to a rod-shaped tool entering loops, a powerful imagery from the feminine sphere for her husband's dysfunctional sexual abilities.

${ }^{23}$ Práinn is repeatedly portrayed as a flawed and impetuous character, as is thoroughly analysed by Ármann Jakobsson (2009).

${ }^{24}$ See further below, but thirteen of those cases concern Hallgerðr: allkátr (32), ást (47), beiskr (104), bliðða (33), djarfliga (85), feginn (183), geisa (99), skappungt (31, 34), stilla sik (48), and unna $(31,44,48)$. Five instances are about Unnr Marðardóttir: skappungt (22), dapr (22), blíðr (25-26), and vera fátt um með (22); one about Bergpóra: geisa (114). Additionally, the feelings of Gunnarr's mother Rannveig are noted twice: feginn (192) and œði mikil (194), and once each in the cases of Pórhildr skáldkona: reiðask (89); Hildigunnr Starkaðardóttir: skappungt (290), and Gunnarr's aunt, Guðlaug: unna (424).
} 
men and women unna 'love'. However, some words are only used to describe women's feelings. All of these instances are in matters related to their spouses, as in most of the twenty-four cases. Dapr 'sad' is reserved for a single person, denoting Unnr Marðardóttir's depressed feelings about her marriage with Hrútr (22). Hallgerðr is the only person who becomes beiskr 'embittered' (104). Skappungt 'sad', literally: 'of heavy mind' appears four times, all in cases about women. ${ }^{25}$

A woman's anger is mentioned four times. Apart from reiðask in the above example of Pórhildr skáldkona, the verb geisa (with the amplifying adverb mjok) is used twice, and $\propto$ ¿ $i$ (with the amplifier mikil) is used once:

Hallgerðr leitaði á Gunnar mjọk, er hann hafði sætzk á vígit [...] hon geisaði mjok.

[Bergbóra] kom innar í annat sinn ok geisaði mjok. (114)

Rannveig spratt upp af œði mikilli. (194)
'Hallgerðr harassed Gunnarr much for having settled the slaying $[\ldots]$ she raged greatly'.

'Bergpóra came in again and raged greatly'.

'Rannveig jumped up in great rage'.

Geisa refers to rage, raving, and a rampage: to lose control. It is often used in Old Norse texts to describe warfare, fire, or destructive and wild waters and sea. ${ }^{26} E \partial i$ similarly refers to frenzy, fury, and even madness. These words connote a much more unrefined, uncontrolled expression of anger than the royal anger or noble anger that has an outlet in just actions, which is described above in the cases of men. Both geisa and $е ð i$ connote a loss of control or extremes: something bursting open with force and fury. This is thus a different kind of anger (or expression of anger) than when the word reiðask is used, and it is exclusively used concerning women in Njáls saga.

These uncontrolled expressions of women's anger are met with disdain. As noted above, Pórhildr's husband becomes furious, divorces her on the spot, and throws her out of the house. Hallgerðr's expression of anger using the terms geisaði mjok is dismissed with an ignoring silence by

\footnotetext{
${ }^{25}$ Unnr Marðardóttir (22); Hallgerðr Họskuldsdóttir $(31,34)$; Hildigunnr Starkaðardóttir (290). The word is mentioned once in four other sagas, Fljótsdcela saga, Hallfreðar saga vandræðaskálds, Vápnfirðinga saga, and Fóstbrœðra saga, in each case referring to a woman, except in Fóstbrœðra saga. See "skappungt" in Mörkuð ílensk málheild: Fornrit; and "skappungr" in Ordbog over det norrøne prosasprog.

${ }^{26}$ See examples of "geisa" in Ordbog over det norrøne prosasprog.
} 
her husband: "Gunnarr gaf eigi gaum at pvî” (99), 'Gunnar ignored this'. When Bergpóra geisaði mjǫk 'raged greatly', her husband Njáll reacts in a similar depreciating way, advising a calm reaction (114), and her son Skarpheðinn demeans his mother's expression with these words: "Ekki họfu vér kvenna skap [...] at vér reiðimsk við olllu” (114), "We do not have the temper of women, who become angry over anything' ${ }^{27}$

\subsection{Words used about Hallgerðr}

As noted above, women's emotions are mentioned twenty-four times in the saga. Thirteen of those cases concern Hallgerðr, which emphasizes her central role in the first part of the saga. In comparison, only Gunnarr's and Flosi Pórðarson's emotions are mentioned more often. The following list shows the number of times for the characters whose feelings are most frequently referred to with emotion words:

29 Gunnarr Hámundarson

17 Flosi Pórðarson

13 Hallgerðr Hǫskuldsdóttir

8 Kári Sǫlmundarson

8 Jarl Hákon

7 Skarpheðinn Njálsson

7 Mǫrðr Valgarðsson

6 Njáll Porgeirsson

The emotion words used about Gunnarr mostly refer to his anger or courage (twenty-one out of twenty-nine) in various feuds and political situations, with the important and notable exception of when he expresses his regret of being forced to slay people (139). In contrast, the emotion words used about Hallgerðr are more expressive and nuanced and offer a deeper view into her psyche, underlining her complexity as a character

\footnotetext{
${ }^{27}$ In all those three cases, the women have attacked or put in question the men's honour. However, this is not the case when Gunnarr's mother Rannveig has œð i mikil, and in that case her expression is not met with disdain. For the treatment of women in Njáls saga and female gender roles in the saga, see Dronke (1981) and essays by Helga Kress (1996). On how the saga discusses gender roles in relation to masculinity in particular, see Ármann Jakobsson (2007).
} 
- as opposed to Gunnarr who is portrayed on a narrower emotional spectrum as a somewhat stereotypical idealized saga hero.

Hallgerðr is a proud woman, who is described as tall and beautiful with long, silky hair $(6,29)$. She is noted to be "skaphorð” (29) 'of harsh temper' by the narrator and "blandin mjok" (86) 'of mixed temperament' by her uncle, and this is stated to be a significant defect and bad currency when negotiations of her marriages are conducted (42,86-87). Blandin mjok insinuates insidiousness and a duplicitous nature, alluding to her many sides that are portrayed in the saga ${ }^{28}$ Hallgerðr's character is unruly and provocative and is representative of an ambivalent strong female figure who disturbs the patriarchal hierarchy within the saga, and also receives the blame for quite a few misfortunes that unfold in the narrative. ${ }^{29}$

However, it is possible to discern a slightly more tender portrayal of her emotions before her marriage to Gunnarr than after she marries him. The first time Hallgerðr's feelings are noted using an emotion word is when her father betroths her to her first husband without asking for her consent. She sadly conveys to her father that this confirms what she long suspected, "at pú mundir eigi unna mér svá mikit sem pú sagðir jafnan” (31), 'that you do not love me as much as you have often said', and the narrator further notes that this makes her "skappungt" (31) 'sad', lit. 'of heavy mind'. However, she is already plotting to get rid of Porvaldr, the husband, and perhaps because of that, she is "allkát" (32) 'very cheerful' at their wedding and deceptively shows "blíðu” (33) 'tenderness' towards Porvaldr. Soon after, Porvaldr slaps her and again she becomes "skappungt” (34) 'sad' and has him killed. Glúmr Óleifsson is her next husband, whom she loves very much, as she says herself: "Vel er um ástir okkrar" (47), 'the love between us is good' Their interaction even includes a description of her embracing him (47), a rare gesture to be noted in the sagas. ${ }^{30}$ When Glúmr slaps her too, the description of her feelings is unusually rich: "Hon unni honum mikit ok mátti eigi stilla sik ok grét hástọfum" (48), 'She loved him much and could not control herself and cried loudly'. Here, it is both noted how much she loved Glúmr and that her emotions are unrestrained, as in the case of the anger of Bergpóra, Pórhildr, and Rannveig. Another exceptional word is used when

\footnotetext{
${ }^{28}$ Zoe Borovsky explores the connotations of adj. blandinn in Old Norse myths and suggests that, in Hallgerðr's case, it is to be taken as a reference to paganism and the old value system, along with allusions to otherness, "a "giant" past that disrupts" the peaceful order. Borovsky (2002: 10-11)

${ }^{29}$ On Hallgerðr's figure, see, e.g., Heinrichs (1994); Helga Kress (2007).

${ }^{30}$ See examples from the corpus of embracing in Wolf (2013: 110-11).
} 
she meets Gunnarr for the first time, and it is noted how "djarfliga" (85) 'daringly, boldly' she speaks to him in their courting scene. This seems to be the only example in the whole corpus of Íslendingasögur where this word is used about a woman. ${ }^{31}$ However, at this point in the saga, the descriptions of her tender heavy mood or feelings of affection end, and words that depict her as more emotionally strained and angry begin to be used.

After having married Gunnarr, she is often cross at him for not reacting to Bergpóra's insults towards her. The insults make her "beisk" (104) 'embittered, acrimonious' and once she "geisaði mjok" (99) 'raged greatly' towards Gunnarr, which, as described above, insinuates uncontrolled anger. There are frequent efforts to tame and discipline her: "Ver pú dæl, meðan ek em heiman, ok sýn af pér enga fárskapi, par sem við vini mína er um at eiga" Gunnarr warns her (92), 'Be compliant while I am away, and do not exercise any malevolence where my friends are concerned'. "Trǫll hafi pína vini”, she replies (92), 'May trolls have your friends'. Gunnarr later slaps Hallgerðr for thievery, to which she answers coldly that she will remember that slap and repay it (124). When Gunnarr decides to stay in Iceland at the risk of being killed with impunity, she becomes "fegin" (183) 'joyful' and it is left ambiguous in the text whether she is joyful out of pride that her husband does not yield to his enemies or because she knows this most likely signals his death.

Thus, though Hallgerðr's feelings are mentioned much less frequently with emotion words than Gunnarr's feelings are, the words that are used provide the reader with a wider and more intense range of emotions from intimate love to fierce contempt, from heavy heart to cheerfulness and great rage - which produces more insight into her psychology than most other characters. This also demonstrates how specifically the emotive vocabulary of the saga is used, as many words are bespoke for the occasion and character.

\section{Conclusion}

This essay described the development and construction of the first lexicons of emotion words in Njáls saga and Egils saga. The lexicons

\footnotetext{
${ }^{31}$ According to a search for "djarflegur" in all forms in the database Mörkuð islensk málheild: Fornrit.
} 
were presented and analysed. It was confirmed that both sagas have a vocabulary for a large spectrum of emotions. These are divided into many categories, each including a range of expressions. Furthermore, it was established how the lexicons can be used as a tool for uncovering narrative patterns, literary constructions of gender and status, and formulas for character development. The analysis reveals that the two works apply their emotional vocabulary in somewhat different settings and scenes, and different categories are prominent.

Egils saga has a slightly larger vocabulary of emotion words. It also has numerous instances of communicating anger, joy, and love in the context of royal anger, which resonates with the fact that aspects of the saga bear a resemblance to the genre of konungasögur. The fact that the biggest emotion categories in the saga are JOY and LOVE can be explained by this feature, and this does not indicate that these are prominent emotional themes in the saga as a whole. This underlines how individual scenes, or a particular formula, skews the overall picture that the lexicon reveals, and advises that no assumptions about the general themes in these sagas can be made based only on a list or a word count. Furthermore, the results show that Egils saga fits the general assumption of self-expression and the narrative voice in Íslendingasögur, in the sense that the majority of the emotion words in Egils saga are spoken by the narrator, but if the word is spoken by a character about his or her own emotions, it is most often in poetry where a more internal perspective can be found.

Njáls saga, on the other hand, has more characters expressing themselves directly regarding their own inner state. Clear gender differences exist in the application of specific words, where some words are only used about women, such as skappungt 'sad, of heavy mind', geisa 'rage', and $е ð i$ mikil 'great rage'. Few cases of this exist, but they nevertheless show that women's anger is termed differently and has different characteristics than men's anger; the connotation of the words is that female anger is less controlled and wilder and calls for reactions of disdain.

It is notable that each of the two sagas has a rather different set of emotion words. When the two lexicons are taken together, they include 164 individual words. Only thirty-six of them are found in both sagas. The analysis further reveals that only a minority of the words $35 \%$ in Njáls saga and 24\% in Egils saga) are used more than once or twice. In many cases, these more common words form a part of a narrative formula, where similar or the same wording is applied in a similar setting throughout the work. This is the case of anger words in the context of royal anger, 
of rejoicing at the return of someone with the words feginn and feginsamliga, and the case of describing being in an intimate relationship with a king with the word karleikr. The majority of the words $(65 \%$ in Njáls saga and $76 \%$ in Egils saga) are only used once or twice and are thus applied in specific, precise settings.

When the above is considered, the emotional vocabulary of Egils saga and Njáls saga can indeed be regarded as diverse and varied, and containing terms for a broad spectrum of emotions. It has been shown here how emotion words are applied in a customized and selected way to describe the emotions of the poet Egill and of Ásgerðr, Hallgerðr, Bergpóra, Gunnarr, and Njáll as well as other characters, and each bespoke choice of words emphasizes the specific features of the characters and their function and place within the narrative. Furthermore, I have addressed how the specificity of the application of the words underlines ideas of femininity, masculinity, status, and honour. The fact that most of the words are used for a particular purpose demonstrates that emotion words are applied in the saga in a systematic and precise way. The variety of nuances within the same emotion category further demonstrates the breadth of the emotive vocabulary. These findings do not altogether agree with previous views that maintain that the emotive vocabulary of the sagas is poor and not very nuanced and that the use of emotion words in them is infrequent and limited.

In the absence of a similar study on other literary works, either medieval or modern, it is difficult to estimate whether the frequency of emotion words in Njáls saga and Egils saga should be considered high or low compared to other works. In Egils saga, 3.1\% of the lexemes are emotion words, which is slightly more than in Njáls saga, where $2.5 \%$ of the lexemes are emotion words. The sagas are also somewhat similar in how often emotion words are applied. The total word count of emotion words in Njáls saga is $0.25 \%$ of the total word count in the saga. In Egils saga, the proportion of emotion words is slightly higher at $0.31 \%$ of all the words of the saga.

A brief examination of the short Viglundar saga can provide at least one indicative point of comparison. Víglundar saga is a love story that is categorized as an Íslendingasaga but has strong stylistic features associated with romances (see Jóhannes Halldórsson 1959: xxxi; Vésteinn Ólason 2006: 157-58). The saga includes twenty-two stanzas and is classified as a late saga, argued to be composed in the early fifteenth century (Vésteinn Ólason 2005: 115). The Svart á hvítu edition, which is available 
in a digital form, is included in the database Mörkuð islensk málheild and includes 12,585 words. Ninety-four occurrences of emotion words can be listed from the saga by the same method and criteria as described above. Thus, $0.74 \%$ of the words in the saga are emotion words, which is a greater ratio than in Njáls saga and Egils saga.

The strong stylistic romance features of the saga manifest for example in the following passage, which includes expressions in a style that would be unthinkable in Egils saga and Njáls saga:

En pau unnust pví heitara með leyniligri ást ok fólginni elsku peim í brjósti pegar í fyrstu, er pau váru uppvaxandi, svá at rætr elskunnar ok uppvöxtr ástarinnar, er aldri varð upprættr ór peira hjörtum, eptir pví sem náttúra er amorsins, at eldr yndisins ok logi elskunnar brennr pví heitara ok sækir pví meir brjóst ok hjörtu mannanna saman sem fleiri vilja peim meina [...] (Víglundar saga 1959: 82).

(But they loved each other even more with secret affection and love that was hidden in their bosom, from the time when they were growing up, so that the roots of affection and the growth of love could never be uprooted from their hearts, because such is the nature of amor, that the fire of pleasure and the flame of love burns hotter, and more strongly besets the breasts and hearts of men, as more people try to forbid it $[\ldots]$ )

This passage includes long strings of emotion words where the amorous feelings of Víglundr and Ketilríor are analysed, explained, and pondered adding references to heat and fire. It is hardly a surprise that almost half (forty) of the occurrences of emotion words in Víglundar saga denote love or affection. However, almost all the emotion words in this passage from Víglundar saga are also found in Njáls saga. The difference between the two sagas' depiction of emotions rather consists in how these words are used. Each time amorous feelings between a man and woman are communicated through words in Njáls saga, only one or two emotion words are applied:

[Hallgerðr] unni [Glúmi] mikit ok mátti eigi stilla sik ok grét hástǫfum. (48)

Práinn unni [Pórhildi] lítit. (87)

„Vel er um ástir okkrar“. (47)

Gunnarr lagði hug á Bergljótu, frændkonu jarls. (83)
'Hallgerðr loved Glúmr much and could not contain herself and cried loudly'.

'Práinn loved Pórhildr little'.

“"The love between us is good".

'Gunnarr desired Bergljót, kinswoman of the jarl'. 
Here, the articulation is blunt and not dwelt on through words with emotive content. Perhaps it is primarily in this sense that the claims that the readers of sagas are "seldom assisted by native emotion words" (Miller 1992: 107), can be justified. Emotive scenes in both Njáls saga and Egils saga certainly do contain emotion words, but they do not form a part of a string of such words when they appear, nor is emotive language used to elaborate on the emotions. Rather, the words appear few at a time and are applied in a specific, concise way. Moreover, the connotations and placements of the words in the text are loaded with meaning that should not be overlooked as inconsequential in the literary interpretation of the sagas.

\section{Bibliography}

\section{Manuscripts}

Den Arnamagnceanske Samling, Copenhagen

AM 468 4to (Reykjabók)

Stofnun Árna Magnússonar í íslenskum fraðum, Reykjavík

AM 132 fol. (Möðruvallabók)

AM 133 fol. (Kálfalækjarbók)

AM 462 4to (Ketilsbók)

AM 551 a 4to

\section{Primary Sources}

Brennu-Njáls saga, 1954. Ed. by Einar Ó1. Sveinsson. Íslenzk fornrit 12. Reykjavík: Hið íslenzka fornritafélag.

Brennu-Njáls saga, 1985. Ed. by Jón Torfason and others. In: Íslendingasögur. Vol. 1. Reykjavík: Svart á hvítu. Pp. 124-345.

Egils saga, 1985. Ed. by Jón Torfason and others. In: Íslendingasögur. Vol. 1. Reykjavík: Svart á hvítu. Pp. 368-518.

Egils saga Skalla-Grímssonar, 1933. Ed. by Sigurður Nordal. Íslenzk fornrit 2. Reykjavík: Hið íslenzka fornritafélag.

Egils saga Skallagrímssonar, tilligemed Egils större kvad, 1886-88. Ed. by Finnur Jónsson. Copenhagen: Samfund til udgivelse af gammel nordisk litteratur.

Fljótsdcela saga, 1950. Ed. by Jón Jóhannsson. In: Austfirðinga sǫgur. Íslenzk fornrit 11. Pp. 213-96. Reykjavík: Hið íslenzka fornritafélag. 
Fóstbrœðra saga, 1943. Ed. by Guðni Jónsson. In: Vestfirðinga sǫgur. Íslenzk fornrit 6. Pp. 121-276. Reykjavík: Hið íslenzka fornritafélag.

Hallfreðar saga vandrceðaskálds, 1939. Ed. by Einar Ól. Sveinsson. In: Vatnsdœla saga, Hallfreðar saga, Kormáks saga, Hrómundar páttr halta, Hrafns páttr Guðrúnarsonar. Íslenzk fornrit 7. Pp. 133-200. Reykjavík: Hið íslenzka fornritafélag.

Heimskringla $=$ Snorri Sturluson, 1991: Heimskringla. Ed. by Bergljót S. Kristjánsdóttir and others. 2 vols. Reykjavík: Mál og menning.

Njála: Udgivet efter gamle håndskrifter af Det kongelige nordiske oldskriftselskab, 1875-1889. Ed. by Konráð Gíslason and Eiríkur Jónsson. 2 vols. Copenhagen: Det Kongelige Nordiske Oldskrift-Selskab.

Óláfs saga Tryggvasonar en mesta , 1958-2000. Ed. by Ólafur Halldórsson. 3 vols . Editiones Arnamagnæanæ, Series A, 1-3. Copenhagen: Ejnar Munksgaard.

Vápnfirðinga saga, 1950. Ed. by Jón Jóhannesson. In: Austfirðinga sögur. Íslenzk fornrit 11. Reykjavík: Hið íslenzka fornritafélag. Pp. 23-65.

Víglundar saga, 1959. Ed. by Jóhannes Halldórsson. In: Kjalnesinga saga. Íslenzk fornrit 14. Reykjavík: Hið íslenzka fornritafélag. Pp. 61-116.

\section{Secondary Literature}

Althoff, Gerd, 1998: "Ira Regis": Prolegomena to a History of Royal Anger. In: Anger's Past: The Social Uses of an Emotion in the Middle Ages. Ed. by B. H. Rosenwein. Ithaca: Cornell University Press. Pp. 59-74.

Ármann Jakobsson, 2002: Our Norwegian Friend: The Role of the King in the Family Sagas. Arkiv för nordisk filologi 117. Pp. 145-160.

—, 2007: Masculinity and Politics in Njáls saga. Viator 38. Pp. 191-215.

- , 2008: "Egils saga" and Empathy: Emotions and Moral Issues in a Dysfunctional Saga Family. Scandinavian Studies 80. Pp. 1-18.

—-, 2009: The Impetuousness of Práinn Sigfússon: Leadership, Virtue and Villainy in Njáls saga. Arkiv för nordisk filologi 124. Pp. 52-67.

Bandlien, Bjørn, 2005: Man or Monster? Negotiations of Masculinity in Old Norse Society. Doctoral thesis, University of Oslo.

Barton, Richard E., 1998: "Zealous Anger" and the Renegotiation of Aristocratic Relationships in Eleventh- and Twelfth-Century France. In: Anger's Past: The Social Uses of an Emotion in the Middle Ages. Ed. by B. H. Rosenwein. Ithaca: Cornell University Press. Pp. 153-170.

Borovsky, Zoe, 2002: "En hon er blandin mjok": Women and Insults in Old Norse literature. In: Cold Counsel: Women in Old Norse Literature and Mythology. Ed. by S. M. Anderson and K. Swenson. London: Routledge. Pp. 1-14.

Bredsdorff, Thomas, 2001: Chaos and Love: The Philosophy of the Icelandic Family Sagas. Trans. by John Tucker. Copenhagen: Museum Tusculanum Press, University of Copenhagen.

Clore, Gerald L., Andrew Ortony, and Mark A. Foss, 1987: The Psychological 
Foundations of the Affective Lexicon. Journal of Personality and Social Psychology 53. Pp. 751-766.

Dronke, Ursula, 1981: The Role of Sexual Themes in Njáls saga. London: Viking Society for Northern Research, University College London.

Ekman, Paul, 1994: All Emotions are Basic. In: The Nature of Emotions: Fundamental Questions. Ed. by P. Ekman and R. J. Davidson. Oxford: Oxford University Press. Pp. 15-19.

Ekman, Paul, and Daniel Cordaro, 2011: What is Meant by Calling Emotions Basic. Emotion Review 3. Pp. 364-370.

Goddard, Cliff, and Anna Wierzbicka, 2014: Words and Meanings: Lexical Semantics Across Domains, Languages, and Cultures. Oxford: Oxford University Press.

Hallberg, Peter, 1966: Några anteckningar om replik och dialog i Njals saga. In: Festschrift Walter Baetke dargebracht zu seinem 80. Geburtstag am 28. März 1964. Ed. by K. Rudolph, R. Heller and E. Walter. Weimar: Hermann Böhlaus Nachfolger. Pp. 130-150.

Haukur Porgeirsson, 2018: How Similar are Heimskringla and Egils saga? An Application of Burrows' Delta to Icelandic Texts. European Journal of Scandinavian Studies 48. Pp. 1-18.

Heinrichs, Anne, 1994: Hallgerðrs Saga in der Njála: Der doppelte Blick. In: Studien zum Altgermanischen: Festschrift für Heinrich Beck. Ed. by H. Uecker. Berlin: De Gruyter. Pp. 327-53.

Helga Kress, 1996: Fyrir dyrum fóstru: Greinar um konur og kynferði í íslenskum fornbókmenntum. Reykjavík: Háskóli Íslands, Rannsóknarstofa í kvennafræðum.

__, 2007: "Fá mér leppa tvo": Nokkur orð um Hallgerði og hárið. Torfhildur 1. Pp. 96-109.

Hunt, Tony, 1983: The Lion and Yvain. In: The Legend of Arthur in the Middle Ages: Studies Presented to A. H. Diverres by Colleagues, Pupils and Friends. Ed. by P. B. Grout, R. A. Lodge, C. E. Pickford and E. K. C. Varty. Cambridge: Brewer. Pp. 86-98.

Izard, Carrol E., 1977: Human Emotions. London: Plenum Press.

Jóhannes Halldórsson, 1959: Formáli. In: Kjalnesinga saga. Ed. by Jóhannes Halldórsson. Íslenzk fornit 14. Reykjavík: Hið íslenzka fornritafélag. Pp. vlxxvi.

Johnson-Laird, P. N., and Keith Oatley, 1989: The Language of Emotions: An Analysis of a Semantic Field. Cognition and Emotion 3. Pp. 81-123.

Jón Viðar Sigurðsson, 2017: Viking Friendship: The Social Bond in Iceland and Norway, c. 900-1300. Ithaca: Cornell University Press.

Kaster, Robert A., 2005: Emotion, Restraint, and Community in Ancient Rome. Oxford: Oxford University Press.

Knuuttila, Simo, 2004: Emotions in Ancient and Medieval Philosophy. Oxford: Oxford University Press. 
Larrington, Carolyne, 2015: Learning to Feel in the Old Norse Camelot? Scandinavian Studies 87. Pp. 74-94.

Matthías Pórðarson, 1914: Ýmislegt um gamla vefstaðinn. In: Árbók Hins íslenzka fornleifafélags. Reykjavík: Hið íslenzka fornleifafélag. Pp. 17-26.

Meulengracht Sørensen, Preben, 1983: The Unmanly Man: Concepts of Sexual Defamation in Early Northern Society. Trans. by Joan Turville-Petre. Odense: Odense University Press.

Miller, Willam Ian, 1992: Emotions and the Sagas. In: From Sagas to Society: Comparative Approaches to Early Iceland. Ed. by Gísli Pálsson. Middlesex: Hisarlik Press. Pp. 89-109.

- 1993: Humiliation and Other Essays on Honor, Social Discomfort, and Violence. Ithaca: Cornell University Press.

Mörður Árnason (ed.), 2007: Íslensk orðabók. 4th ed. Reykjavík: Edda. <https:// snara.is>.

Mörkuð íslensk málheild: Fornrit. Stofnun Árna Magnússonar í íslenskum fræðum, 2012-2017. <http://mim.arnastofnun.is/>.

Niedenthal, Paula M., 2008: Emotion Concepts. In: Handbook of Emotions. Ed. by M. Lewis, J. M. Haviland-Jones and L. Feldmann Barrett. New York: Guilford. Pp. 587-600.

OED Online. Oxford English Dictionary. Oxford University Press. <http://oed. com>.

Ordbog over det norrøne prosasprog. Index of medieval manuscripts. Den Arnamagnæanske Kommission. <http://onp.ku.dk/>.

Porter, Edel, and Teodoro Manrique Antón, 2015: Flushing in Anger, Blushing in Shame: Somatic Markers in Old Norse Emotional Expressions. Cognitive Linguistic Studies 2. Pp. 24-49.

Rosch, Eleanor, 1978: Principles of Categorization. In: Cognition and Categorization. Ed. by E. Rosh and B. B. Lloyd. Hillside: Erlbaum. Pp. 27-48.

Rosenwein, Barbara H., 2008: Emotion Words. In: Le sujet des émotions au moyen âge. Ed. by P. Nagy and D. Boquet. Paris: Beauchesne.

_, 2010: Thinking Historically about Medieval Emotions. History Compass 8, 828-842.

Russell, James A., 1991: Culture and the Categorization of Emotions. Psychological Bulletin 110. Pp. 426-450.

Russell, James A., and Ghyslaine Lemay, 2000: Emotion Concepts. In: Handbook of Emotions. Ed. by M. Lewis and J. M. Haviland-Jones. New York: Guilford. Pp. 491-503.

Shweder, Richard A., Jonathan Haidt, Randall Horton, and Craig Joseph, 2008: The Cultural Psychology of the Emotions: Ancient and Renewed. In: Handbook of Emotions. Ed. by M. Lewis, J. M. Haviland-Jones and L. Feldman Barrett. New York: Guilford Press. Pp. 409-427.

Sif Rikhardsdottir, 2017: Emotions in Old Norse Literature: Translations, Voices, Contexts. Cambridge: Brewer. 
Svanhildur Óskarsdóttir, 1991: Um Brennu-Njáls sögu. In: Brennu-Njáls saga. Ed. by Örnólfur Thorsson. Reykjavík: Mál og menning. Pp. vii-xxv.

Sverrir Tómasson, and Örnólfur Thorsson, 1991: Um Íslendinga sögur. In: Brennu-Njáls saga. Ed. by Örnólfur Thorsson. Reykjavík: Mál og menning. Pp. 483-557.

Sävborg, Daniel, 2007: Sagan om kärleken: Erotik, känslor och berättarkonst i norrön litteratur. Acta Universitatis Upsaliensis 27. Historia litterarum. Uppsala: Uppsala University.

__, 2017: Style. In: The Routledge Research Companion to the Medieval Icelandic Sagas. Ed. by Ármann Jakobsson and Sverrir Jakobsson. London: Routledge. Pp. 111-127.

Torfi H. Tulinius, 2004: Skáldið í skriftinni: Snorri Sturluson og Egils saga. Ritröð Reykjavíkur Akademíunnar og Hins íslenska bókmenntafélags 3. Reykjavík: Hið íslenska bókmenntafélag, Reykjavíkur Akademían.

Vésteinn Ólason, 1994: Emosjon og aksjon i “Njáls saga”. Nordica Bergensia 3. Pp. 157-172.

__ 1998: Dialogues with the Viking Age: Narration and Representation in the Sagas of the Icelanders. Trans. by Andrew Wawn. Reykjavík: Heimskringla.

__, 2005: Family Sagas. In: A Companion to Old Norse-Icelandic Literature and Culture. Ed. by R. McTurk. Oxford: Blackwell. Pp. 101-118.

__, 2006: Íslendingasögur og pættir. In: Íslensk bókmenntasaga. Ed. by Vésteinn Ólason. Reykjavík: Mál og menning. Pp. 23-163.

White, Stephen D., 1998: The Politics of Anger. In: Anger's Past: The Social Uses of an Emotion in the Middle Ages. Ed. by B. H. Rosenwein. Ithaca: Cornell University Press. Pp. 127-152.

Wierzbicka, Anna, 1986: Human Emotions: Universal or Culture-Specific? American Anthropologist 88. Pp. 584-594.

__, 1999: Emotions Across Languages and Cultures: Diversity and Universals. Cambridge: Cambridge University Press.

Wolf, Kirsten, 2013: Body Language in Medieval Iceland: A Study of Gesticulation in the Sagas and Tales of Icelanders. Scripta Islandica 64. Pp. 99-122.

__, 2014: Somatic Semiotics: Emotion and the Human Face in the Sagas and Pættir of Icelanders. Traditio 69. Pp. 125-145.

Porleifur Hauksson, and Pórir Óskarsson, 1994: Íslensk stílfræði. Reykjavík: Styrktarsjóður Pórbergs Pórðarsonar og Margrétar Jónsdóttur, Mál og menning. Pórir Óskarsson, 2005: Rhetoric and Style. In: A Companion to Old NorseIcelandic Literature and Culture. Ed. by R. McTurk. Oxford: Blackwell. Pp. 354-371. 


\section{Summary}

Even though scholars have often maintained that the Old Norse Íslendingasögur (Sagas of Icelanders) are poor in emotional vocabulary, the emotion words in them have not been comprehensively explored. In this essay, I explain my construction of database of the words used to express feelings in two of the longest sagas, Njáls saga and Egils saga. The method used enabled the plotting of various variables, such as character, gender, social status, and speaker, against one another. This uncovered narrative patterns and formulas for action, as well as allowing the identification of anomalies and the production of the first lexicons of the two sagas' emotional vocabulary. The results demonstrate that, contrary to what has often been assumed, the sagas contain a wide variety of emotion words that are applied systematically, precisely, and purposefully to achieve specific narrative aims.

Keywords: Emotion words, emotional lexis, lexical investigation, Íslendingasögur, Sagas of Icelanders, Egils saga, Njáls saga

Brynja Porgeirsdóttir

University of Cambridge

Department of Anglo-Saxon, Norse, and Celtic

Cambridge CB3 9DP

United Kingdom

bt346@cam.ac.uk

brynjathorgeirsdottir@gmail.com

ORCID iD 0000-0003-1474-5604 